\title{
Pseudo-nitzschia arctica sp. nov., a new cold-water cryptic Pseudo-nitzschia species within the P. pseudodelicatissima complex
}

\author{
Percopo Isabella ${ }^{1}$, Ruggiero Maria Valeria ${ }^{1}$, Balzano Sergio 2, 5, , Gourvil Priscillia ${ }^{2}$, Lundholm Nina ${ }^{3}$, \\ Siano Raffaele ${ }^{4}$, Tammilehto Anna ${ }^{3}$, Vaulot Daniel ${ }^{2}$, Sarno Diana ${ }^{1,{ }^{*}}$
}

${ }^{1}$ Stn Zool Anton Dohrn, Integrat Marine Ecol Dept, I-80121 Naples, Italy.

2 Univ Paris 06, Univ Paris 04, CNRS, Stn Biol,UMR 7144, PI Georges Teissier, F-29680 Roscoff, France.

3 Univ Copenhagen, Nat Hist Museum Denmark, Solvgade 83S, DK-1307 Copenhagen K, Denmark.

${ }^{4}$ Ctr Brest, IFREMER, DYNECO Pelagos, BP 70, F-29280 Plouzane, France.

5 Nioz Royal Netherlands Inst Sea Res, Dept Marine Organ Biogeochem, POB 59, NL-1790 AB Den

Burg, Netherlands.

*Corresponding author : Diana Sarno,email address : diana.sarno@szn.it

\begin{abstract}
:
A new nontoxic Pseudo-nitzschia species belonging to the P. pseudodelicatissima complex, $\mathrm{P}$. arctica, was isolated from different areas of the Arctic. The erection of $P$. arctica is mainly supported by molecular data, since the species shares identical ultrastructure with another species in the complex, P. fryxelliana, and represents a new case of crypticity within the genus. Despite their morphological similarity, the two species are not closely related in phylogenies based on LSU, ITS and rbcL. Interestingly, P. arctica is phylogenetically most closely related to P. granii and P. subcurvata, from which the species is, however, morphologically different. P. granii and P. subcurvata lack the central larger interspace which is one of the defining features of the P. pseudodelicatissima complex. The close genetic relationship between $\mathrm{P}$. arctica and the two species $P$. granii and $P$. subcurvata is demonstrated by analysis of the secondary structure of ITS2 which revealed no compensatory base changes, two hemi-compensatory base changes, and two deletions in $\mathrm{P}$. arctica with respect to the other two species. These findings emphasize that rates of morphological differentiation, molecular evolution and speciation are often incongruent for Pseudonitzschia species, resulting in a restricted phylogenetic value for taxonomic characters used to discriminate species. The description of a new cryptic species, widely distributed in the Arctic and potentially representing an endemic component of the Arctic diatom flora, reinforces the idea of the existence of noncosmopolitan Pseudo-nitzschia species and highlights the need for combined morphological and molecular analyses to assess the distributional patterns of phytoplankton species.
\end{abstract}

Keywords : Arctic, cryptic, ITS, ITS2 secondary structure, LSU rRNA, morphology, P, arctica sp, nov, phylogeny, Pseudo-nitzschia, rbcL 


\section{Abbreviations}

AIC

Akaike information criterion

ASP

amnesic shellfish poisoning

BIC

Bayesian information criterion

$\mathrm{CBC}$

compensatory base change

DA

domoic acid

$\mathrm{HCBC}$

hemi-compensatory base change

rbcS

Rubisco small subunit gene

SNP

single-nucleotide polymorphism 


\section{INTRODUCTION}

Pseudo-nitzschia H. Peragallo is a world-wide genus of planktonic pennate diatoms, which includes a number of potentially toxic species. After the first ASP (amnesic shellfish poisoning) event in 1987 caused by the species Pseudo-nitzschia multiseries (Hasle) Hasle (Bates et al. 1989), numerous studies have focused on several aspects of taxonomy, ecology, toxicity, and physiology of Pseudo-nitzschia species (Lelong et al. 2012, Trainer et al. 2012). The increased interest in Pseudo-nitzschia biodiversity and distribution clearly resulted in a steady increase in the number of species descriptions (Lelong et al. 2012). Most of the diversity has been discovered within the $P$. pseudodelicatissima complex. The $P$. pseudodelicatissima complex was introduced in 2003 when Lundholm and coauthors emended the species P. pseudodelicatissima (Hasle) Hasle and P. cuspidata (Hasle) Hasle, and described two similar species $P$. caciantha Lundholm, Moestrup and Hasle and $P$. calliantha Lundholm, Moestrup and Hasle based on morphological and molecular (LSU and ITS) data (Lundholm et al. 2003). Since this first study, different genetic markers have been used for molecular taxonomy of Pseudo-nitzschia spp., including the mitochondrion encoded cytochrome c oxidase 1 ( $\operatorname{cox} 1$; Kaczmarska et al. 2008), the chloroplast-encoded genes of the large subunit of ribulose-1,5-bisphosphate carboxylase/oxygenase ( $r b c \mathrm{~L}$; Amato et al. 2007, Casteleyn et al. 2009, Casteleyn et al. 2010) and of the small subunit ( $r b c S$; Delaney et al. 2011). However, the internal transcribed spacer (ITS) of the nuclear ribosomal operon was shown to be the best species discriminator among all tested genetic markers for Pseudonitzschia species (Lundholm et al. 2003, Amato et al. 2007, Casteleyn et al. 2008, Kaczmarska et al. 2008). Information contained in the second internal transcribed spacer (ITS2) has been useful to help the delimitation of some cryptic/pseudo-cryptic species (e.g., P. mannii Amato and Montresor, P. arenysensis Quijano- Scheggia, Garcés, Lundholm, $P$. hasleana Lundholm and P. fryxelliana Lundholm; Amato and Montresor 2008, Quijano- 
Scheggia et al. 2009, Lundholm et al. 2012). Currently, the P. pseudodelicatissima complex alone includes 16 species (Lundholm et al. 2003, Amato et al. 2007, Amato and Montresor 2008, Lim et al. 2012, Lim et al. 2013, Orive et al. 2013, Teng et al. 2014).

The genus Pseudo-nitzschia is known to be distributed worldwide but species biogeography and local phenologies are far from being assessed exhaustively (Hasle 2002). Microscopic observations have suggested that some species seem to be restricted to distinct latitudinal zones. This is particularly evident for a number of cold water species, as is the case of $P$. turgiduloides (Hasle) Hasle and P. subcurvata (Hasle) Fryxell found in the Antarctic waters (Hasle and Syvertsen 1997, Scott and Thomas 2005), or P. granii (Hasle) Hasle recorded in arctic and subarctic waters (Lovejoy et al. 2002, Marchetti et al. 2008). In Arctic waters, in addition to $P$. granii, other Pseudo-nitzschia species have been recorded in sea ice, coastal (Poulin et al. 2011) and offshore waters (Marchetti et al. 2008). In particular, six taxa have been recorded in the arctic waters of Alaska, Canada and Greenland: P. pseudodelicatissima and P. pungens (Grunow ex Cleve) Hasle from Chucky and Beaufort Sea (Booth and Horner 1997, Różańska et al. 2008, Sukhanova et al. 2009), P. obtusa (Hasle) Hasle and Lundholm from Chucky Sea (Booth and Horner 1997), P. delicatissima (Cleve) Heiden, P. seriata (Cleve) H. Peragallo and P. granii from Baffin Bay and Greenland (Lovejoy et al. 2002, Hansen et al. 2011, Hardardotir et al. 2015). A higher number of species have been reported from the Arctic Sea of Russia (Tuschling et al. 2000) and Scandinavia (von Quillfeldt 1997, Ratkova et al. 1998, Wassmann et al. 1999, von Quillfeldt 2000, Ratkova and Wassmann 2002, 2005, Degerlund and Eilertsen 2010). However, information on species occurrence in Arctic waters is generally based on morphological observations acquired using light microscopy. Given the existence of high level of cryptic diversity within the genus, and the evidence that, even at a regional scale, several distinct genetic lineages can coexist and have different seasonality (McDonald et al. 2007, Orive et al. 2013, Ruggiero et al. 2015), the 
biogeography and distribution of cold temperature Pseudo-nitzschia species needs to be reevaluated.

In the present study, we investigate ultrastructure, molecular and toxicity characteristics of six strains of Pseudo-nitzschia, isolated from different regions of the Arctic. One of the isolated strains (P2F2) was previously identified as $P$. delicatissima (Tammilehto et al. 2012) and the other (CCMP1309 $=\mathrm{K} 1142)$ as P.cf. subcurvata . Detailed morphological analyses and the use of discriminating genetic markers (LSU, $r b c \mathrm{~L}$ and ITS, including secondary structure) suggest that all mentioned strains belong to a new species, that we describe as $P$. arctica sp. nov.

\section{MATERIAL AND METHODS}

Samples and cultures. A total of six strains of $P$. arctica were analyzed (Table 1). Four strains were isolated from seawater collected in the Beaufort Sea, at $29 \mathrm{~m}$ in a station located near the Mackenzie River outlet, in the framework of the MALINA cruise which took place in mid-summer 2009. Clonal strains were obtained through single-cell pipette isolation after seawater enrichment. The media used for the enrichments were 2-fold diluted Keller medium (K/2, Keller et al. 1987) for RCC2517 and RCC2002 and Javorski medium (www.ccap.ac.uk/media/recipes/JM.htm) for RCC2004 and RCC2005. The media were adjusted to a salinity of 30 . Both types of enrichments were maintained at $4^{\circ} \mathrm{C}$, in $12: 12$ light:dark conditions under an irradiance $10-20 \mu \mathrm{mol}$ photons $\cdot \mathrm{m}^{-2} \cdot \mathrm{s}^{-1}$ for $3-4$ months before strains isolation. Single-cell pipette isolations were carried out as described previously (Balzano et al. 2012a): samples were observed using an inverted microscope Olympus IX71 (Olympus, Hamburg, Germany) and $1.5 \mathrm{~mL}$ from each sample were collected and transferred into a 24-well Iwaki plate (Starlab, Bagnieux, France). A sample aliquot was transferred into a new well containing sterile medium and this step was repeated 4 times for a final 100,000 
fold dilution of the enriched sample. Single cells were then collected using a Nichipet EX 0.5-10 $\mu \mathrm{L}$ (Starlab, Bagnieux, France), transferred again into new plates containing sterile media and incubated in the same conditions as the enrichment. These cultures are currently (November 2015) available from the Roscoff Culture Collection (http://www.roscoff-culturecollection.org/). They are maintained in K/2 plus Si medium. One other strain (P2F2) was established from field sample in Disko Bay, Greenland, in April 2010, using single-cell isolation techniques. The strain CCMP1309 was isolated from a sample in Barrow Strait, Canada in May 1989 and is available from the NCMA collection (https://ncma.bigelow.org/ccmp1309) where it is identified as $P$. cf. subcurvata. The latter two strains were grown at $4^{\circ} \mathrm{C}$ in L1-medium (Guillard and Morton, 2003), at a salinity of 30 under a light intensity of $100 \mu \mathrm{mol}$ photons $\cdot \mathrm{m}^{-2} \cdot \mathrm{s}^{-1}$ at a 15:9 light:dark cycle using cool white fluorescent bulbs.

Microscopy. Light microscopy (LM) observations and measurements of live cells were carried out using a Zeiss Axiophot light microscope (Carl Zeiss, Oberkochen, Germany) equipped with Nomarski differential interference contrast (DIC), phase contrast (PH) and bright-field (BF) optics. Cell end overlap was measured in colonies observed in girdle view and the percentage of overlap calculated. Pictures were taken with a Zeiss Axiocam digital camera (Carl Zeiss, Oberkochen, Germany). For transmission electron microscopy (TEM) observations, some samples were treated with nitric and sulphuric acids (1:1:4, sample: $\mathrm{HNO}_{3}: \mathrm{H}_{2} \mathrm{SO}_{4}$ ), boiled for some seconds in order to remove the organic matter and washed with distilled water (modified from Round et al. 1990). Other samples were treated according to Lundholm et al. (2002). Acid-cleaned material was mounted on Formvar-coated grids. All grids were observed either using a Philips 400 TEM (Philips Electron Optics BV, Eindhoven, Netherlands) or a JEOL-1010 transmission electron microscope (TEM) (Jeol, 
Tokyo, Japan). Morphometric measurements were taken on TEM images. Approximately twenty valves of each strain were observed.

\section{Molecular analysis}

DNA extraction. For DNA extraction, $2 \mathrm{~mL}$ of culture were collected during the stationary growth phase, centrifuged at $11,000 \mathrm{rpm}$ for $10 \mathrm{~min}$ and $1.8 \mathrm{~mL}$ supernatant removed. For strains RCC2002, RCC2004, RCC2005 and RCC2517, genomic DNA was then extracted from the pellets using Qiagen Blood and Tissue kit (Qiagen, Cortaboeuf, France) as described previously (Balzano et al. 2012b). For strains P2F2 and CCMP1309, genomic DNA was extracted as in Lundholm et al. (2002).

Polymerase chain reaction (PCR) amplification. DNA from each strain was amplified by PCR for the genes of LSU rRNA, ITS1-5.8S-ITS2 and $r b c \mathrm{~L}$. For all PCR reactions, $1 \mu \mathrm{L}$ of genomic DNA was mixed with $0.5 \mu \mathrm{L}$ of $10 \mu \mathrm{M}$ solution of both forward and reverse primers, $15 \mu \mathrm{L}$ of HotStar Taq Plus Master Mix Kit (Qiagen, Courtaboeuf, France), $3 \mu \mathrm{L}$ of Coral Load (Qiagen, Courtaboeuf, France), and Milli-Q water up to a final volume of $30 \mu \mathrm{L}$. The LSU rRNA gene was amplified and sequenced using primers D1R or D3Ca targeting the D1-D3 region of the nuclear LSU rRNA (Orsini et al. 2002). The ITS region of the rRNA operon was amplified and sequenced using the universal primers ITS- 1 and ITS- 4 which amplify very small portions of both $18 \mathrm{~S}$ and LSU rRNA genes and the whole ITS region (White et al. 1990).

The $r b c \mathrm{~L}$ gene was amplified using primers $r b c \mathrm{~L} 1$ and $r b c \mathrm{~L} 7$ (Amato et al. 2007) and PCR reactions included an initial denaturation of $94^{\circ} \mathrm{C}$ for $5 \mathrm{~min}, 35$ amplification cycles $\left(94^{\circ} \mathrm{C}\right.$ for $60 \mathrm{~s}, 60^{\circ} \mathrm{C}$ for $55 \mathrm{~s}$, and $72^{\circ} \mathrm{C}$ for $90 \mathrm{~s}$ ) and a final extension of $5 \mathrm{~min}$ at $72^{\circ} \mathrm{C}$ (see Table $\mathrm{S} 1$ for primer sequences). 
PCR amplicons were purified using exosap (USB products, Santa Clara, USA) and sequences were determined using the Big Dye Terminator V3.1 (Applied Biosystems, Foster, USA). For sequencing, two additional internal primers, $r b c \mathrm{LI} 1 \mathrm{~F}$ and $r b c \mathrm{LI} 1 \mathrm{R}$, were used (Amato et al. 2007) along with the primers described above.

Chromatograms of the sequences obtained were then analyzed by eye to check for the presence of double peaks and nucleotide ambiguities using Bioedit (Hall 1999).

Molecular phylogenies. Pseudo-nitzschia sequences obtained from GenBank for each marker (ITS, LSU and $r b c \mathrm{~L}$ ) were aligned with sequences of our strains using MAFFT (Katoh 2013) (Table S2), with the Q-INS-i options, which incorporates structural information. The LSU rRNA alignment (55 sequences) included $943 \mathrm{bp}$, of which 242 positions were analyzed (26\%), after eliminating all positions containing gaps and missing data. Cylindrotheca fusiformis Reimann and Lewin was used as outgroup. The ITS rRNA (58 sequences) alignment included initially 1401 positions, of which, after eliminating all positions containing gaps and missing data, 609 positions were analyzed (44\%). The ITS analyses were unrooted. The $r b c \mathrm{~L}$ alignment (35 sequences) included $1509 \mathrm{bp}$ of which 1378 positions were analyzed (91\%), after eliminating all positions containing gaps and missing data.

Cylindrotheca sp. was used as outgroup. Sequences of $P$. subcurvata (Accession number: HQ337586 and HQ337585) were too short (748 over 1509 bp of alignment) to be included in the phylogenetic $r b c \mathrm{~L}$ analysis but they were used to estimate the diversity between species using number of net nucleotide substitutions per site between species (Nei 1987). All distance and maximum likelihood analyses were performed in MEGA v5.10 (Tamura et al. 2011). Maximum Likelihood trees were built using MEGA v5.10, with 1,000 bootstrap replicates, based on the substitution model selected through the Akaike information criterion (AIC) option implemented in MEGA v5.10. Bayesian analyses were performed using MrBayes 
3.1.2 (Ronquist and Huelsenbeck 2003), with four chains run for 1,000,000 generations. The temperature was set to 0.2 , sample frequency was 100 , and the number of burn-in generations was $25 \%$ for the each data set. Bayesian Inference was performed with the best model selected through the Bayesian information criterion (BIC) implemented in MEGA v5.10. The number of net nucleotide substitutions per site between species (Nei 1987) was assessed for each marker using the software DNAsp (Librado and Rozas 2009).

\section{Secondary structure of ITS2}

The secondary structure of the ITS-2 from $P$. arctica strain RCC2005 was predicted using mfold (http://unafold.rna.albany.edu, Zuker et al. 1999) using the default parameters: $37^{\circ} \mathrm{C}, 1$ M sodium chloride, $5 \%$ sub-optimality and maximum loop sizes of $30 \mathrm{bp}$. The secondary structure showing the typical folding of the genus Pseudo-nitzschia (i.e., four helices and one pseudohelix $)$ and the lowest free energy $(\mathrm{dG}=-81.40)$ was selected and data were downloaded in dot-bracket notation. The structure of $P$. granii strain RCC2008 was then reconstructed using the ITS2 database (http://its2.bioapps.biozentrum.uni-wuerzburg.de, Wolf et al. 2005) by homology modelling using the secondary structure of $P$. arctica as template. The secondary structures were then visualised and downloaded using VARNA (Darty et al. 2009) to identify compensatory base changes (CBCs) and hemi-compensatory base changes (HCBCs).

\section{Toxin analysis}

Domoic acid (DA) production of strains RCC2002, RCC2004, RCC2005 was screened by an Elisa test kit (Mercury Science). Toxicity tests were carried out on late-stationary phase cultures on material harvested from $50 \mathrm{~mL}$ culture maintained in the standard maintenance conditions $\left(\mathrm{K} / 2+\mathrm{Si}\right.$ medium, $4^{\circ} \mathrm{C}, 70-80 \mu \mathrm{mol}$ photons $\mathrm{m}^{-2} \cdot \mathrm{s}^{-1}, 12: 12$ light:dark regime) 
Culture material was sonicated and then filtered onto GF/F filters. Assays were performed following manufacturer's specifications, using a standard microplate absorbance reader at 450 $\mathrm{nm}$. The assay test used had a limit of detection $0.1 \mu \mathrm{g}$ DA $\mathrm{L}^{-1}$. However Elisa test might be considered as qualitative tests for general screening of DA production. Toxin production of strain P2F2 was tested under two different conditions (see details in Tammilehto et al. 2012): 1) using $50 \%$ silica-reduced L1-medium, under a light intensity of $100 \mu \mathrm{mol}$ photons $\mathrm{m}^{-2} \cdot \mathrm{s}^{-1}$ using 19:5 light:dark cycle. The silica concentration of the L1-medium was reduced in order to trigger domoic acid production as Si-limitation is known to enhance domoic acid production in Pseudo-nitzschia species (e.g., Fehling et al. 2004); 2) under similar conditions and in addition exposed to grazing copepods of the genus Calanus, as this is known to induce DA production (Tammilehto et al. 2012, 2015, Hardardotir et al. 2015). Processing of the material and toxin analyses using Liquid Chromatography-Mass Spectrometry (LC MS/MS) is described in Tammilehto et al. (2012).

\section{RESULTS}

Diagnosis

Pseudo-nitzschia arctica Percopo et Sarno sp. nov. (Fig. 1, A-J; Table 2)

Cells are lanceolate in valve view, linear in girdle view forming stepped colonies with about 1/9-1/12 of cell overlapping. Transapical axis length is: $1.6-2.5 \mu \mathrm{m}$. Central larger interspace is present. Fibulae are not always regularly spaced. 17 to 24 fibulae and 33 to 39 interstriae in $10 \mu \mathrm{m}$. Each stria has one row of rounded poroids. 4 to 6 poroids in $1 \mu \mathrm{m}$. Each poroid contains $1-5$ sectors or consists of less silicified unperforated areas. The cingulum is composed of 3 open bands. The valvocopula has $43-48$ striae in $10 \mu \mathrm{m}$ and is $2-3$ poroids high and 2 poroids wide. The second band is 1 poroid high and 1-2 poroids wide. The second 
band is split in two parts: one with small variable poroids and the other completely unperforated. The third band is generally unperforated.

Holotype: Slide of the strain RCC2005 deposited at the Museum of the Stazione Zoologica A. Dohrn in Napoli, registered as no. SZN-RCC2005/1.

Isotype: Fixed material of RCC2005 deposited at the Museum of the Stazione Zoologica A. Dohrn in Napoli, registered as no. SZN-RCC2005/2.

Illustrations of the type material: Figure 1, F, H and J.

Molecular characterization: DNA sequences for rRNA LSU, ITS and $r b c$ L of strain RCC2005 are deposited in GenBank with accessions number JQ995419, KT808255 and KT808258, respectively.

Type locality: Beaufort Sea, 69.49 N, 137.94 W

Etymology: The epithet arctica (=arctic) refers to the area where the organism was found.

Morphology: Cells are lanceolate in valve view and almost linear with truncated ends in girdle view (Fig. 1, A and B). Cells overlap about 1/9-1/12 of total cell length when forming stepped colonies (Fig. 1A). Valvar transapical axis length is $1.6-2.5 \mu \mathrm{m}$, apical axis $26-67$ $\mu \mathrm{m}$ (Table 2). Valves are tapering towards the ends with rounded apices (Fig. 1, B-D). A central larger interspace is present (Fig.1, E and G). The fibulae are not always regularly spaced. The densities of fibulae and interstriae are 17-24 and 33-39 in $10 \mu \mathrm{m}$, respectively. Each stria contains one row of rounded poroids with a density of $4-6$ poroids in $1 \mu \mathrm{m}$ (Fig. 1 , E-I; Table 2). The mantle is often 1-2 poroids high and has a composition similar to the valve (Fig. 1F). Each poroid contains 1-5 sectors of varying size and lacks a central sector. The most frequent number of sectors in the examined strains is 1-3 (Fig. 1, E-I). In some cases, the poroids simply consist of less silicified areas without any perforation (Fig. 1, E-I). The 
cingulum is composed of 3 open bands (Fig. 1, F and J-L). The valvocopula contains 41-48 striae in $10 \mu \mathrm{m}$ and is 2 and seldom 3 poroids high and 2 poroids wide (Fig. 1, J-L; Table 2). The second band contains a longitudinal row of variable size poroids and an unperforated part (Fig. 1, J and L). The third band is generally unperforated and has rarely a few scattered minute pores (Fig. 1J). A certain variability was observed among the different strains of $P$. arctica; in particular, the strain RCC2004 has poroids with a higher number of dividing sectors (up to 5) with a central sector rarely present (Fig. 1G), and in the strain P2F2 the valvocopula tends to be slightly more silicified and 3 instead of 2 poroids high, the second band has more defined and larger poroids and the third band is often perforated by minute pores (Fig. 1K).

\section{Toxicity}

Toxicity tests on $P$. arctica strains for domoic acid production were negative for both ELISA tests (strains RCC2002, RCC2004, RCC2005) and LC MS/MS analyses (strain P2F2).

\section{Phylogenetic analysis}

Phylogenies based on LSU (Fig. S1 in the Supporting Information), ITS and ITS2 (Fig. 2 and Fig. S2 in the Supporting Information), and $r b c \mathrm{~L}$ (Fig. 3) showed P. arctica strains clustering together in a well-supported clade (LSU : 99/100, ITS: 99/1.00, ITS2: 99/1.00, $r b c$ L: 100/1.00, , bootstrap and Bayesian values, respectively), as sister to a clade comprising $P$. granii and $P$. subcurvata. LSU, ITS and $r b c \mathrm{~L}$ sequences were identical for all strains of $P$. arctica (although the $r b c \mathrm{~L}$ sequence for P2F2 and CCMP1309 were not available). Notably, ITS GenBank sequences of CCMP2093 isolated from the arctic Nunavut, Canada, originally assigned to $P$. cf. granii, is identical to $P$. arctica ITS sequences, and should be reassigned to P. arctica. 
Genetic distances between $P$. arctica and its closest relatives, $P$. granii and $P$. subcurvata were small for all markers. $P$. granii and $P$. subcurvata were more closely related to each other than to $P$. arctica. Divergence values were variable among different genetic markers when comparing $P$. arctica with the other two closely related species, with LSU showing the lowest values and $r b c \mathrm{~L}$ the highest (Table 3).

\section{Secondary structure of ITS2}

ITS2 secondary structure of $P$. arctica presented the typical folding with four helices plus the additional helix IIa, characteristic of the genus Pseudo-nitzschia (Fig. 4). Secondary structures were compared among $P$. arctica and its sister species $P$. granii and $P$. subcurvata. No CBCs, two HCBCs and four SNPs (single-nucleotide polymorphisms) were observed between $P$. arctica and the closely related species $P$. granii and $P$. subcurvata. One HCBC is present in helix I (G-U $\leftrightarrow$ A-U) and another in helix III (G-U↔U-A). Four SNPs were also

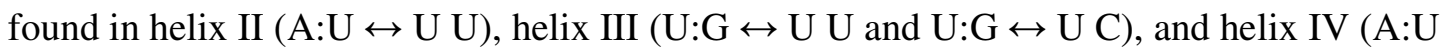
$\leftrightarrow \mathrm{U} \mathrm{U}$ for $P$. granii and A-U $\leftrightarrow \mathrm{C} \mathrm{U}$ for $P$. subcurvata). Two nucleotide insertions (GA) were found for both $P$. granii and $P$. subcurvata with respect to P. arctica on helix III (Fig. 4) and such insertions changed the folding of the tip of helix III. P. granii and P. subcurvata only differed by a base change in a loop of helix IV (U U↔C U) (Fig. 4).

\section{DISCUSSION}

Morphologically, $P$. arctica belongs to the $P$. pseudodelicatissima complex including species having lanceolate to linear narrow valves (transapical axis less than $3.0 \mu \mathrm{m}$ ), uniseriate striae and a central larger interspace. According to this definition, the complex comprises 17 species, P. arctica, P. abrensis Pérez-Aicua and Orive, P. batesiana H.C. Lim, S.T. Teng, C.P. Leaw, and P.T. Lim, P. caciantha, P. calliantha, P. circumpora H.C. Lim, C.P. Leaw and P.T. Lim, P. cuspidata, P. fryxelliana Lundholm, P. fukuyoi H.C. Lim, S.T. Teng, C.P. 
Leaw, and P.T. Lim, P. hasleana, P. inflatula (Hasle) Hasle, P. kodamae S.T. Teng, H.C. Lim, C.P. Leaw and P.T. Lim, P. lineola (Cleve) Hasle, P. lundholmiae H.C. Lim, S.T. Teng, C.P. Leaw, and P.T. Lim, P. mannii, P. plurisecta Orive and Pérez-Aicua and $P$. pseudodelicatissima (Lundholm et al. 2003, Amato et al. 2007, Amato and Montresor 2008, Lim et al. 2012, Lundholm et al. 2012, Lim et al. 2013, Orive et al. 2013, Teng et al. 2014). The shape of the cells is very similar among species and size ranges often overlap. A comparison of cell length is affected by the lack of knowledge of the maximum cell size for most species. Species identification is not possible using light microscopy, since it is based on a combination of fine ultrastructural differences, i.e., number of poroid sectors, density of fibulae, striae and band striae, and structure of the valvocopula, which require the use of electron microscopy. Molecular analyses are often required to further support the morphological species identification.

The recognition of $P$. arctica as a new species is supported by molecular data, as $P$. arctica shares a very similar ultrastructure with at least one other species in the complex, namely $P$. fryxelliana. Besides having a comparable number of interstriae (33-39 in P. arctica and 3440 in P. fryxelliana), fibulae (17-24 and 18-25, respectively), poroid density (4-6 and 5-6 in $1 \mu \mathrm{m}$, respectively) and band striae (41-48 and 41-50, respectively), the two species share a remarkable and peculiar variability in poroid structure. In both species, the number and the size of sectors in the poroids can vary from 1 to 5 even in the same stria. In addition, some striae are simply composed of very lightly silicified poroid hymen without any perforations.

Within the complex, $P$. arctica shows also morphological similarities with $P$. abrensis, $P$. hasleana, P. mannii and P. plurisecta. However, P. abrensis can be differentiated by having a lower density of band interstriae (36-38 vs 41-48), and P. hasleana a lower density of fibulae 
(13-20 vs 17-24). In addition, $P$. hasleana, $P$. mannii and especially $P$. plurisecta have a higher number of sectors in poroids than $P$. $\operatorname{arctica}(2-6,2-7$ and 3-10 respectively $v s 0-5)$.

P. batesiana, $P$. caciantha, $P$. circumpora, $P$. fukuyoi, $P$. kodamae and $P$. lundholmiae have a lower density of fibulae and interstriae than $P$. arctica (see Table 2). In addition, $P$. caciantha, $P$. circumpora and $P$. kodamae are slightly wider and $P$. fukuyoi is slightly narrower than $P$. arctica $(2.2-3.5,2.2-2.7,1.5-1.9$ and $1.5-1.9 \mu \mathrm{m}$, respectively $v s 1.6-2.5$ $\mu \mathrm{m})$. P. lundholmiae, moreover, has the poroid hymen generally divided into 1-2 sectors and a lower density of band striae. $P$. circumpora is characterized by a distinctive pore arrangement in the poroids, with the fine pores in each perforation sector arranged in circles, and the presence of rare biseriate striae together with dominant uniseriate striae.

$P$. arctica can easily be differentiated from $P$. cuspidata, $P$. inflatula and $P$. pseudodelicatissima because the 3 latter species have poroids divided into only two sectors whereas the poroids from $P$. arctica consist in a variable number of sectors (0-5). Moreover P. cuspidata and P. pseudodelicatissima have a higher density of interstriae than $P$. arctica (35-44 and 36-43 vs 33-39). Pseudo-nitzschia pseudodelicatissima tends also to be narrower than $P$. arctica $(0.9-1.6 \mu \mathrm{m} v s 1.6-2.5 \mu \mathrm{m})$.

P. arctica is well distinguishable from $P$. lineola which has the lowest density of fibulae, interstriae and band striae among the species belonging to the complex $(10.5-15.5,22-31$, 22-34 respectively). Moreover, $P$. lineola has a slightly atypical stria ultrastructure, having simple poroids organized in 1-2 rows, whereas all the other species have more complex poroids which are always arranged in a single row. 
Interestingly, $P$. arctica is morphologically very different from the phylogenetically closely related species, $P$. granii and $P$. subcurvata. The two latter species lack the central large interspace and therefore do not even belong to the P. pseudodelicatissima complex. In addition, $P$. arctica has fewer interstriae (33-39 in $P$. arctica , 43-55 in $P$. granii, and 44-55 in $P$. subcurvata) and more fibulae $(17-24,12-22$, and $12-20$, respectively) than $P$. granii and P. arctica.

Pseudo-nitzschia granii and $P$. subcurvata are ultrastructurally very similar to each other and are only differentiated by a different cell shape, which is however different from the species belonging to the $P$. pseudodelicatissima complex. $P$. granii has a spindle shaped valve and rounded apices (Hasle and Syvertsen 1997, Marchetti et al. 2008). Pseudo-nitzschia subcurvata has a typical curved valve outline with a dilated middle part, one side of the valve straight or slightly concave and the other side convex (Hasle and Syvertsen 1997, Almandoz et al. 2008).

Despite being phylogenetically close to $P$. granii and $P$. subcurvata, $P$. arctica can be considered a distinct genetic unit, as shown by LSU, ITS, $r b c$ L phylogenies and supported by the genetic divergence data (Figs. 2, 3, S1, S2; Table 3). In particular, $r b c \mathrm{~L}$ phylogeny indicates that $P$. arctica and $P$. granii are two different species. $R b c \mathrm{~L}$ was proven to be more efficient than LSU in discriminating diatom species and the last $738 \mathrm{bp}$ of the $r b c \mathrm{~L}$ gene have been proposed for diatom barcoding (Hamsher et al. 2011). In comparison to a nuclearencoded marker like ITS, $r b c \mathrm{~L}$ can be more easily amplified, sequenced and aligned. In addition, being a photosynthetic region, it is unlikely to amplify heterotrophic contaminant DNA (MacGillivary and Kaczmarska 2011). The $r b c$ L gene has been previously used for the genus Pseudo-nitzschia. This gene seems to have a high taxonomic resolution since it can discriminate between closely related taxa such as $P$. pungens var. pungens and $P$. pungens 
var. cingulata (Casteleyn et al. 2009). However the resolutive power of a shorter fragment of the $r b c \mathrm{~L}$ seems to be insufficient for Pseudo-nitzschia barcoding (MacGillivary and Kaczmarska 2011). The extent of the taxonomic resolution of the full $r b c \mathrm{~L}$ for the genus Pseudo-nitzschia varies according to the species investigated and can be either higher or lower than that of the ITS (Amato et al. 2007). Our data seem to confirm the phylogenetic and taxonomic value of $r b c \mathrm{~L}$ within the genus Pseudo-nitzschia, but the efficacy of this marker needs to be assessed based on a larger number of species.

The recognition of $P$. arctica as a separate species is also supported by the analysis of the secondary structure of the ITS2. The presence of CBCs or HCBCs can be used to infer the existence of reproductive isolation in congeneric species (Behnke et al. 2004, Vanormelingen et al. 2007, Coleman 2009). This approach has been largely used in the delineation of Pseudo-nitzschia species (e.g., Amato et al. 2007, Casteleyn et al. 2008, Kaczmarska et al. 2008, Lundholm et al. 2012, Lim et al. 2013, Orive et al. 2013, Teng et al. 2015). The analysis of the secondary structure of the ITS2 of all our strains of $P$. arctica shows 2 HCBCs and 2 nucleotide deletions compared to $P$. granii and $P$. subcurvata. These differences, especially the HCBCs in the helix I and the helix III of the ITS2 (Fig. 4), suggest reproductive isolation between $P$. arctica and its two sister species. Although it has been noticed that the presence of $\mathrm{CBCs}$ is significantly correlated with mating incompatibility (Coleman 2000, 2005), post-zygotic incompatibility was already observed within the genus Pseudo-nitzschia between two species differing only by HCBCs. P. calliantha and P. mannii, which showed just two HCBCs in helix I and two in helix III, were able to mate but not to form viable auxospores, indicating that a speciation process is in progress due to post-zygotic sexual barriers (Amato et al. 2007, Amato and Montresor 2008). 
The morphological and genetic similarity between $P$. granii and $P$. subcurvata, including the presence of a single base change in a loop on helix IV, is intriguing. Strains from the same species can have HCBCs in the helix IV as found in Pseudo-nitzschia sabit S.T. Teng, H.C. Lim, P.T. Lim and C.P. Leaw (Teng et al. 2015), and in general genotypes sharing $100 \%$ identity in the helix II and helix III are considered to belong to the same species. Further investigations, including mating experiments, are required in order to assess whether $P$. granii and $P$. subcurvata are separate species or different genotypes of a single bipolar species.

Despite their morphological similarity, $P$. fryxelliana and $P$. arctica appear in distant positions in all phylogenetic trees. Moreover, the genetic distance between the two species, based on ITS (ITS: 0.133, ITS2: 0.203), is larger than the distance observed between other cryptic species, e.g., the distance between $P$. delicatissima and $P$. decipiens (ITS: 0.0750.090) (Lundholm et al. 2006) or between P. delicatissima and P. arenysensis (ITS2: 0.1) (Quijano-Scheggia et al. 2009).

The description of $P$. arctica, which is morphologically similar to $P$. fryxelliana, represents another case of a cryptic species within the $P$. pseudodelicatissima complex. Cryptic diversity has been unveiled in several planktonic and benthic, freshwater and marine microalgal genera, including Skeletonema (Sarno et al. 2005, 2007) and Cyclotella, (Beszteri et al. 2007, Evans et al. 2008). Within the Pseudo-nitzschia complex, crypticity has already been shown to exist between $P$. pseudodelicatissima and P. cuspidata. The two species share identical ultrastructure and only show slight differences in the valve shape, with the former being linear and the latter lanceolate, which become unclear after repetitive vegetative divisions and the resulting reduction in valve length (Lundholm et al. 2003, 2012). However, the distinction 
between the two species remains unresolved using LSU rRNA (Amato et al 2007, Lim et al. 2012, this study) and only partially resolved by ITS analyses (Lundholm et al. 2003, 2006, 2012, Lim et al. 2013, Orive et al. 2013). Only the incorporation of the ITS2 secondary structure in the phylogenetic reconstruction allowed to the separation of the P. cuspidata strain Tenerife8 from the P. pseudodelicatissima clade (Lim et al. 2013). Similarly, within the $P$. delicatissima complex, $P$. delicatissima and $P$. arenysensis are distinguishable only by molecular evidences (Quijano-Scheggia et al. 2009). In both cases, differently from what observed in $P$. arctica and $P$. fryxelliana, the cryptic species are phylogenetically closely related.

All these findings point out that rates of morphological differentiation, molecular evolution and speciation are incongruent for some Pseudo-nitzschia species, as already demonstrated in other planktonic organisms (Lee and Frost 2002, Logares et al. 2007, André et al. 2013).

A direct consequence of the discordant paces of morphological and molecular evolution is the resulting lack of phylogenetic value for some of the taxonomic characters so far considered important for separating Pseudo-nitzschia species. The absence/presence of a larger central interspace, i.e., raphe entire or disconnected by a central siliceous nodule, was traditionally considered an important character for species identification in Pseudo-nitzschia (Hasle 1965). Initial molecular analyses suggested this feature could have phylogenetic meaning (Orsini et al. 2002), but this hypothesis has been disproven (Lim et al. 2013) and is further challenged in the present study. Similarly, the two morphological features used to circumscribe species belonging to the $P$. pseudodelicatissima complex, i.e., presence of uniseriate striae and poroids divided in sectors, have been demonstrated to be phylogenetically uninformative since the first species descriptions (Lundholm et al. 2002, 2012, Lim et al. 2013). Here we 
confirm that the P. pseudodelicatissima complex is not monophyletic (Figs. 2, 3, S1 and S2) and that the morphological characters used to discriminate species in the complex are not phylogenetically meaningful, confirming similar speculations for other diatoms, as for example the Cyclotella meneghiniana complex (Beszteri et al. 2007, Evans et al. 2008).

The fact that the intraspecific variability of certain morphological traits is difficult to assess limits the use of diagnostic characters for species delimitation. In P. arctica, similarly to what observed in $P$. fryxelliana and $P$. hasleana (Lundholm et al., 2012), the ultrastructure of poroids, i.e. the number and size of sectors in the poroids, has been shown to vary among valves of a clonal culture and even among the poroids within a single stria. Only a few studies have focused on frustule ultrastructure plasticity in Pseudo-nitzschia species and effect of the environmental factors on morphological characters (Falasco et al. 2009). For example, temperature affects the number of rows of poroids in P. multiseries (Lewis et al. 1993) and the number of rows and the density of poroids in P. seriata (Hansen et al. 2011). Similarly, it has been found that salinity plays a significant role in the morphological plasticity of the frustule of Thalassiosira punctigera (Castracane) Hasle and T. weissflogii (Grunow) G.Fryxell and Hasle (Vrieling et al. 2007) and Cocconeis placentula Ehrenberg and C. pinnata W.Gregory ex Greville (Leterme et al. 2013), with main effects on pore size. These observations question the validity of the use of the ultrastructure of poroids for species discrimination and stress the importance of the assessment of the morphology based on environmental samples as culture conditions might induce morphological changes. In this study, P. arctica morphology has been described based on culture material. Only slight variations in the number of sectors of the poroids and in the level of silification/perforation of the valvocopula have been observed among the 6 strains analyzed, one of which was established in culture in 1989, which have been grown in different culture conditions and 
media. Nevertheless, any significant interstrain variability in the main morphological features used to define Pseudo-nitzschia species (i.e., presence of the central larger interspace, number of striae and fibulae, poroids density) has been detected.

\section{Production of domoic acid}

Neither of the strains tested positive in any of the tests for production of DA. Negative Elisa test assays do not exclude the possibility of production DA in very low concentrations or under different physiological conditions. The tests of strain P2F2 was, however, performed using LC-MS/MS and induction of domoic acid was attempted both by exposing the strain to silica depletion and grazing by Calanus copepods. Silica depletion has previously been shown to increase DA production in several Pseudo-nitzschia species (Bates et al. 1998, Fehling et al. 2004), and copepod grazing has been shown to induce DA production in at least two other Arctic Pseudo-nitzschia species, P. seriata and P. obtusa (Tammilehto et al. 2015, Hardardotir et al. 2015). We thus assume that $P$. arctica is non-toxic, although we cannot exclude that other strains can be toxic.

\section{Biogeography}

Strains of $P$. arctica analysed in the present study were collected at three distant localities in the Arctic, i.e., the Beaufort Sea, the West Greenland and the Northwest Territories, in different years and in two different seasons (spring and summer). The ITS sequence available in GenBank and identical to $P$. arctica named $P$. cf. granii CCMP2093 was isolated from Nunavut, Canada in 1998. These findings question the validity of the Pseudo-nitzschia reports from the Canadian Basin based on LM, especially those referring to P. delicatissima and P. pseudodelicatissima (Horner and Schrader 1982, Booth and Horner 1997, Różańska et al. 2008, Sukhanova et al. 2009), with whom P. arctica can be easily confused using light 
microscopy. Our results suggest that $P$. arctica has a distribution confined to the northern polar area, possibly representing one of the endemic components of the Arctic diatom flora (Balzano et al. 2015, in preparation). The existence of cold-adapted, geographically restricted ecotypes has been suggested for other Arctic phytoplankton taxa such as the diatom Chaetoceros neogracilis (Schütt) VanLandingham, and the Arctic ecotype of the cosmopolitan polyphyletic green alga, Micromonas pusilla (Butcher) Manton and Parke, the two autotrophic protists identified as Arctic phylotypes based on their 18S rRNA gene sequence (Lovejoy et al. 2007, Lovejoy and Potvin 2011). Within the genus Pseudonitzschia, other species appear to be restricted to polar/subpolar waters, i.e. $P$. granii and $P$. obtusa for the Northern area and P. turgiduloides, $P$. subcurvata and $P$. prolongatoides for the Southern area. $P$. seriata shows a wider latitudinal distribution, still circumscribed to the northern hemisphere, being recorded from temperate as well as Arctic regions of the North Atlantic (Hasle and Lundholm 2005). The doubtful report of specimens of $P$. seriata with an atypical stria ultrastructure from the Beagle Channel of Argentina requires further investigation, as pointed out by the authors themselves (Almandoz et al. 2009). Similarly, the unexpected finding of specimens attributed to $P$. cf. subcurvata along the Mexican coast of the Gulf of Mexico (Aké-Castillo \& Okolodkov 2009) has been recently explained by the description of a new species, $P$. sabit, from plankton samples collected from the Malacca Strait, Malaysia, and the Pacific coast of Mexico (Teng et al. 2015).

A limited number of Pseudo-nitzschia species seems to have restricted distribution in nonpolar areas (Lelong et al. 2012). However, assessment of the distributional patterns of cryptic and/or recently described Pseudo-nitzschia species will require the use of combined morphological and molecular analyses on material collected in different study areas, including the tropical regions, which are characterized by a high species diversity (Lim et al. 
2012, 2013, Teng et al. 2014). Based on the available information, a worldwide distribution seems to be common to most of Pseudo-nitzschia species. Cosmopolitism, which was tentatively proposed for most DA-producing taxa (Hasle 2002), has been confirmed for many species after the introduction of molecular approaches in Pseudo-nitzschia identification (Lelong et al. 2012). Notably, the use of more variable molecular markers can reveal biogeographic patterns within cosmopolitan species, at the intraspecific level. Distinct distribution patterns characterize the three ITS clades of $P$. pungens which correspond to the morphological varieties $P$. pungens var. pungens, $P$. pungens var. cingulata and $P$. pungens var. aveirensis (Casteleyn et al. 2008, 2009, Churro et al. 2009, Lim et al. 2014).

Microsatellite analyses showed that $P$. pungens var. pungens has a significant geographic genetic structuring with very restricted gene flow between the different geographical populations (Casteleyn et al. 2010). In P. pungens, different physiological features are correlated with morphological and genetic intraspecific differentiation (Kim et al. 2015).

Our observations reinforce the idea of the existence of non-cosmopolitan Pseudo-nitzschia species, as already suggested by the distribution patterns of other cold-water species. The incongruity shown here between taxonomy based on morphological characters and molecular phylogeny complicate the study of the genus Pseudo-nitzschia but makes Pseudonitzschia a genus suitable to address interesting questions on speciation and evolution in diatoms.

\section{ACKNOWLEDGMENTS}

We are grateful to F. Iamunno and R. Graziano (Electron Microscopy Service, SZN) for EM support, and A. Amato for his valuable suggestions. The study was supported by the EU projects ASSEMBLE-FP7-INFRA-2008-227799 (grant for IP), the Italian RITMARE 
flagship Project, funded by MIUR under the NRP 2011-2013, approved by the CIPE

Resolution 2/2011 of 23.03.2011 (grant for MVR) and MaCuMBA (FP7-KBBE-2012-6311975).

\section{REFERENCES}

Aké-Castillo, J. A. \& Okolodkov, J. B. 2009. Pseudo-nitzschia subcurvata

(Bacillariophyceae) in the Gulf of Mexico? Harmful Algae News 40:6-7.

Almandoz, G. O., Ferreyra, G. A., Schloss, I. R., Dogliotti, A. I., Rupolo V., Paparazzo, F. E., Esteves J. L. \& Ferrario, M. E. 2008. Distribution and ecology of Pseudo-nitzschia species (Bacillariophyceae) in surface waters of the Weddell Sea (Antarctica). Polar Biol. 31:429-42.

Almandoz G. O., Hernando M. \& Ferrario M. E. 2009. SEM observations of Pseudonitzschia from Beagle Channel: P. seriata in the southern hemisphere? Harmful Algae News 39:6-7.

Amato, A., Kooistra, W. H. C. F., Levialdi Ghiron, J. H., Mann, D. G., Pröschold, T. \& Montresor, M. 2007. Reproductive isolation among sympatric cryptic species in marine diatoms. Protist 158:193-207.

Amato, A. \& Montresor, M. 2008. Morphology, phylogeny, and sexual cycle of Pseudonitzschia mannii sp. nov. (Bacillariophyceae): a pseudo-cryptic species within the $P$. pseudodelicatissima complex. Phycologia 47:487-97. 
André, A., Agnes, W., Frédéric, Q., Aurahs, R., Raphaël, M., Douady, C., J., de GaridelThoron, T., Escarguel, G., de Vargas, C. \& Kucera, M. 2013. The cryptic and the apparent reversed: lack of genetic differentiation within the morphologically diverse plexus of the planktonic foraminifer Globigerinoides sacculifer. Paleobiology 39:21-39.

Balzano, S., Gourvil, P., Siano, R., Chanoine, M., Marie, D., Lessard, S., Sarno, D. \& Vaulot, D. 2012a. Diversity of cultured photosynthetic flagellates in the northeast Pacific and Arctic Oceans in summer. Biogeosciences 9:4553-71.

Balzano, S., Marie, D., Gourvil, P. \& Vaulot, D. 2012b. Composition of the summer photosynthetic pico and nanoplankton communities in the Beaufort Sea assessed by T-RFLP and sequences of the 18S rRNA gene from flowcytometry sorted samples. ISME J. 6:148098.

Balzano, S., Percopo, I., Siano, R., Gourvil, P., Chanoine, M., Marie, D., Vaulot, D. \& Sarno, D. 2015. Diatom diversity in the Beaufort Sea (Canadian Arctic). in preparation.

Bates, S. S., Bird, C. J., Freitas, A. S. W. D., Foxall, R., Gilgan, M. W., Hanic, L. A., Johnson, J. E., McCulloch, A. W., Odense, P., Pocklington, R., Quilliam, M. A., Sim, P. G., Smith, J. C., Rao, D. V. S., Todd, E. C. D., Walter, J. A. \& Wright, J. L. C. 1989. Pennate diatom Nitzschia pungens as the primary source of domoic acid, a toxin in shellfish from eastern Prince Edward Island, Canada. Can. J. Fish. Aquat. Sci. 46:1203-15.

Bates, S. S., Garrison, D. L. \& Horner, R. A. 1998. Bloom dynamics and physiology of domoic acid-producing Pseudo-nitzschia species. In Anderson, D. M., Cembella, A. D. \& 
Hallegraeff, G. M. [Eds.] Physiological Ecology of Harmful Algal Blooms., Heidelberg: Springer-Verlag, pp. 267-92.

Behnke, A., Friedl, T., Chepurnov, V. A. \& Mann, D. G. 2004. Reproductive compatibility and rDNA sequence analyses in Sellaphora pupula species complex (Bacillariophyta). $J$. Phycol. 40:193-208.

Beszteri, B., John, U. \& Medlin, L. K. 2007. An assessment of cryptic genetic diversity within the Cyclotella meneghiniana species complex (Bacillariophyta) based on nuclear and plastid genes, and amplified fragment length polymorphisms. Eur. J. Phycol. 42:47-60.

Booth, B. C. \& Horner, R. A. 1997. Microalgae on the Arctic Ocean Section, 1994: species abundance and biomass. Deep-Sea Res. II 44:1607-22.

Casteleyn, G., Chepurnov, V. A., Leliaert, F., Mann, D. G., Bates, S. S., Lundholm, N., Rhodes, L., Sabbe, K. \& Vyverman, W. 2008. Pseudo-nitzschia pungens (Bacillariophyceae): A cosmopolitan diatom species? Harmful Algae 7:241-57.

Casteleyn, G., Evans, K. M., Backeljau, T., D’hondt, S., Chepurnov, V. A., Sabbe, K. \& Vyverman, W. 2009. Lack of population genetic structuring in the marine planktonic diatom Pseudo-nitzschia pungens (Bacillariophyceae) in a heterogeneous area in the Southern Bight of the North Sea. Mar. Biol. 156:1149-58. 
Casteleyn, G., Leliaert, F., Backeljau, T., Debeer, A.-E., Kotaki, Y., Rhodes, L., Lundholm, N., Sabbe, K. \& Vyverman, W. 2010. Limits to gene flow in a cosmopolitan marine planktonic diatom. Proc. Nat. Acad. Sci. USA 107:12952-57.

Churro, C. I., Carreira, C. C., Rodrigues, F. J., Craveiro, S. C., Calado, A. J., Casteleyn, G. \& Lundholm, N. 2009. Diversity and abundance of potentially toxic Pseudo-nitzschia Peragallo in Aveiro coastal lagoon, Portugal and description of a new variety, P. pungens var. aveirensis var. nov. Diatom Res. 24:35-62.

Cleve, P. T. 1897. Report of the Phyto-Expedition of H.M.S. "Research". Fifteenth Ann. Rep. of the Fish. Board of Scotland. 3:296-304.

Coleman, A. W. 2000. The significance of a coincidence between evolutionary landmarks found in mating affinity and a DNA sequence. Protist 151:1-9.

Coleman, A. W. 2005. Paramecium aurelia revisited. J. Eukaryot. Microbiol. 52: 68-77

Coleman, A. W. 2009. Is there a molecular key to the level of "biological species" in eukaryotes? A DNA guide. Mol. Phylogenet. Evol. 50:197-203.

Darty, K., Denise, A., \& Ponty, Y. 2009. VARNA: Interactive drawing and editing of the RNA secondary structure. Bioinformatics 25:1974-75.

Degerlund, M. \& Eilertsen, H. 2010. Main species characteristics of phytoplankton spring blooms in NE Atlantic and Arctic waters (68-80 N). Estuar. Coast. 33:242-69. 
Delaney, J. A. , Ulrich, R. M. \& Paul, J. H. 2011. Detection of the toxic marine diatom Pseudo-nitzschia multiseries using the RuBisCO small subunit $(r b c \mathrm{~S})$ gene in two real-time RNA amplification formats. Harmful Algae 11:54-64.

Evans, K. M., Wortley, A. H., Simpson, G. E., Chepurnov, V. A. \& Mann, D. G. 2008. A molecular systematic approach to explore diversity within the Sellaphora pupula species complex (Bacillariophyta) J. Phycol. 44:215-31.

Falasco, E., Bona, F., Badino, G., Hoffmann, L. \& Ector, L. 2009. Diatom teratological forms and environmental alterations: a review. Hydrobiologia 623:1-35.

Fehling, J., Davidson, K., Bolch, C. \& Bates, S. S. 2004. Growth and domoic acid production by Pseudo-nitzschia seriata (Bacillariophyceae) under phosphate and silicate limitation. $J$. Phycol. 40:674-83.

Guillard, R. R. L. \& Morton, S. L. 2003. Culture methods. In: Hallegraeff, G. M., Anderson, D. M., Cembella, A. D. [Ed.] Manual on Harmful Marine Microalgae. UNESCO, pp. 77-97.

Hall, T. A. 1999. BioEdit: a user-friendly biological sequence alignment editor and analysis program for Windows 95/98/NT. Nucl. Acid. S. 41:95-98.

Hamsher, S. E., Evans, K. M., Mann, D. G., Poulícková, A. \& Saunders, G. W. 2011. Barcoding Diatoms: Exploring Alternatives to COI-5P. Protist 162:405-22. 
Hansen, L. R., Soylu, S. I, Kotaki, Y., Moestrup, Ø. \& Lundholm, N. 2011. Toxin production and temperature-induced morphological variation of the diatom Pseudo-nitzschia seriata from the Arctic. Harmful Algae 10:689-96.

Hardardotir, S., Pančić, P., Tammilehto A., Nielsen T. G., Krock B., Møller E. F. \& Lundholm, N. 2015. Dangerous relations in the arctic marine food web - interactions between domoic acid producing Pseudo-nitzschia diatoms and Calanus copepodites. Marine Drugs 13, 3809-35.

Hasle, G. 1965. Nitzschia and Fragilariopsis species studied in the light and electron microscopes. II. The group Pseudo-nitzschia. Skr. Nor. Vidensk-Akad. Oslo I MatNaturvidensk. Kl. 18: 1-45.

Hasle, G. R. 2002. Are most of the domoic acid-producing species of the diatom genus Pseudo-nitzschia cosmopolites? Harmful Algae 1:137-46.

Hasle, G. R. \& Syvertsen, E. E. 1997. Marine diatoms. In: Tomas, C. R. [Ed.] Identifying marine phytoplankton. Academic Press, San Diego, pp. 5-385.

Hasle, G. R. \& Lundholm, N. 2005. Pseudo-nitzschia seriata f. obtusa (Bacillariophyceae) raised in rank based on morphological, phylogenetic and distributional data. Phycologia 44:608-19. 
Horner, R. \& Schrader, G. C. 1982. Relative contributions of ice algae, phytoplankton, and benthic microalgae to primary production in nearshore regions of the Beaufort Sea. Arctic $35: 485-503$.

Kaczmarska, I., Reid, C., Martin, J. L. \& Moniz, M. B. J. 2008. Morphological, biological, and molecular characteristics of the diatom Pseudo-nitzschia delicatissima from the Canadian Maritimes. Botany 86:763-72.

Katoh, S. 2013. MAFFT multiple sequence alignment software version 7: improvements in performance and usability. Mol. Biol. Evol. 30:772-80.

Keller, M. D., Selvin, R. C., Claus, W. \& Guillard, R. R. L. 1987. Media for the culture of oceanic ultraphytoplankton. J. Phycol. 23:633-38.

Kim, J. H., Park, B. S., Kim, J.-H., Wang, P. \& Han, M.-S. 2015. Intraspecific diversity and distribution of the cosmopolitan species Pseudo-nitzschia pungens (Bacillariophyceae): morphology, genetics, and ecophysiology of the three clades. J. Phycol. 51:159-72.

Lee, C. E. \& Frost, B. W. 2002. Morphological stasis in the Eurytemora affinis species complex (Copepoda : Temoridae). Hydrobiologia 480:111-28.

Lelong, A., Hégaret, H., Soudant, P. \& Bates, S. S. 2012. Pseudo-nitzschia (Bacillariophyceae) species, domoic acid and amnesic shellfish poisoning: revisiting previous paradigms. Phycologia 51:168-216. 
Leterme, S. C., Prime, E., Mitchell, J., Brown, M. H. \& Ellis, A. V. 2013. Diatom adaptability to environmental change: a case study of two Cocconeis species from highsalinity areas. Diatom Res. 28:29-35.

Lewis, N. I., Bates, S. S., McLachlan, J. L. \& Smith, J. C. 1993. Temperature effects on growth, domoic acid production, and morphology of the diatom Nitzschia pungens $\mathrm{f}$. multiseries. In Smayda, T. J. \& Shimizu, Y. [Eds.] Toxic Phytoplankton Blooms in the Sea. Elsevier Sci. Publ. B.V., Amsterdam, The Netherlands, pp. 601-6.

Librado, P. \& Rozas, J. 2009. DnaSP v5: a software for comprehensive analysis of DNA polymorphism data. Bioinformatics 25:1451-52.

Lim, H. C., Leaw, C. P., Su, S. N. P., Teng, S. T., Usup, G., Mohammad-Noor, N., Lundholm, N., Kotaki, Y. \& Lim, P. T. 2012. Morphology and molecular characterization of Pseudo-nitzschia (Bacillariophyceae) from Malaysian Borneo, including the new species Pseudo-nitzschia circumpora sp. nov. J. Phycol. 48:1232-47.

Lim, H. C., Teng, S. T., Leaw, C. P. \& Lim, P. T. 2013. Three novel species in the Pseudonitzschia pseudodelicatissima complex: $P$. batesiana sp. nov., $P$. lundholmiae sp. nov., and P. fukuyoi sp. nov. (Bacillariophyceae) from the Strait of Malacca, Malaysia. J. Phycol. 49:902-16.

Lim, H. C., Lim, P. T., Teng, S. T. \& Bates, S. S. 2014. Genetic structure of Pseudo-nitzschia pungens (Bacillariophyceae) populations: implications of a global diversification of the diatom. Harmful Algae 37:142-52. 
Logares, R., Rengefors, K., Kremp, A., Shalchian-Tabrizi, K., Boltovskoy, A., Tengs, T., Shurtleff, A. \& Klaveness, D. 2007. Phenotypically different microalgal morphospecies with identical ribosomal DNA: A case of rapid adaptive evolution? Microb. Ecol. 53:549-61.

Lovejoy, C., Legendre, L., Marie-Josée, M., Julie, B. \& von Quillfeldt C.H. 2002. Distribution of phytoplankton and other protists in the North Water. Deep Sea Res. II 49:5027-47.

Lovejoy, C. \& Potvin, M. 2011. Microbial eukaryotic distribution in a dynamic Beaufort Sea and the Arctic Ocean. J. Plankton Res. 33:431-44

Lovejoy, C., Vincent, W. F., Bonilla, S., Roy, S., Martineau, M.-J., Terrado, R., Potvin, M., Massana, R., Pedrós-Alió, C. 2007. Distribution, phylogeny, and growth of cold-adapted picoprasinophytes in arctic seas. J. Phycol. 43:78-89

Lundholm, N., Daugbjerg, N. \& Moestrup, Ø. 2002. Phylogeny of the Bacillariaceae with emphasis on the genus Pseudo-nitzschia (Bacillariophyceae) based on partial LSU rDNA. Eur. J. Phycol. 37:115-34.

Lundholm, N., Moestrup, Ø., Hasle, G. R. \& Hoef-Emden, K. 2003. A study of the Pseudonitzschia pseudodelicatissima/cuspidata complex (Bacillariophyceae): what is $P$. pseudodelicatissima? J. Phycol. 39:797-813. 
Lundholm, N., Moestrup, Ø., Kotaki, Y., Hoef-Emden, K., Scholin, C. \& Miller, P. 2006. Inter- and intraspecific variation of the Pseudo-nitzschia delicatissima complex (Bacillariophyceae) illustrated by rRNA probes, morphological data and phylogenetic analyses. J. Phycol. 42:464-81.

Lundholm, N., Bates, S. S., Baugh, K. A., Bill, B. D., Connell, L. B., Léger, C. \& Trainer, V. L. 2012. Cryptic and pseudo-cryptic diversity in diatoms-with descriptions of Pseudonitzschia hasleana sp. nov. and P. fryxelliana sp. nov. J. Phycol. 48:436-54.

MacGillivary, M. \& Kaczmarska, I. 2011. Survey of the efficacy of a short fragment of the $r b c \mathrm{~L}$ gene as a supplemental DNA barcode for diatoms. J. Euk. Microbiol. 58:529-536.

Marchetti, A., Lundholm, N., Kotaki, Y., Hubbard, K., Harrison, P. J. \& Armbrust, E. V. 2008. Identification and assessment of domoic acid production in oceanic Pseudo-nitzschia (Bacillariophyceae) from iron-limited waters in the North-East subartcic Pacific. J. Phycol. $44: 650-61$.

McDonald, S. M., Sarno, D. \& Zingone, A. 2007. Identifying Pseudo-nitzschia species in natural samples using genus-specific PCR primers and clone libraries. Harmful Algae 6:84960.

Nei, M. 1987. Molecular Evolutionary Genetics. Columbia Univ. Press, New York, 512 pp.

Orive, E., Pérez-Aicua, L., David, H., García-Etxebarria, K., Laza-Martínez, A., Seoane, S. \& Miguel, I. 2013. The genus Pseudo-nitzschia (Bacillariophyceae) in a temperate estuary with 
description of two new species: Pseudo-nitzschia plurisecta sp. nov. and Pseudo-nitzschia abrensis sp. nov. J. Phycol. 49:1192-206.

Orsini, L., Sarno, D., Procaccini, G., Poletti, R., Dahlmann, J. \& Montresor, M. 2002. Toxic Pseudo-nitzschia multistriata (Bacillariophyceae) from the Gulf of Naples: morphology, toxin analysis and phylogenetic relationships with other Pseudo-nitzschia species. Eur. J. Phycol. 37:247-57.

Poulin, M., Daugbjerg, N., Gradinger, R., Ludmila, I., Tatiana, R. \& von Quillfeldt, C. 2011. The pan-Arctic biodiversity of marine pelagic and sea-ice unicellular eukaryotes: a firstattempt assessment. Mar. Biodiv. 41:13-28.

Priisholm, K., Moestrup, Ø.\& Lundholm, N. 2002. Taxonomic notes on the marine diatom genus Pseudo-nitzschia in the Andaman Sea near the island of Phuket, Thailand, with a description of Pseudo-nitzschia micropora sp. nov. Diatom Res. 17:153-75.

Quijano-Scheggia, S. I., Garcés, E., Lundholm, N., Moestrup, Ø., Andree, K. \& Camp, J. 2009. Morphology, physiology, molecular phylogeny and sexual compatibility of the cryptic Pseudo-nitzschia delicatissima complex (Bacillariophyta), including the description of $P$. arenysensis sp. nov. Phycologia 48:492-509.

Ratkova, T. N., Wassmann, P., Verity, P. G. \& Andreassen, I. J. 1998. Abundance and biomass of pico-, nano-, and microplankton on a transect across Nordvestbanken, north Norwegian shelf, in 1994. Sarsia 84:213-25. 
Ratkova, T. N. \& Wassmann, P. 2002. Seasonal variation and spatial distribution of phytoand protozooplankton in the central Barents Sea. J. Marine Syst. 38:47-75.

Ratkova, T. N. \& Wassmann, P. 2005. Sea ice algae in the White and Barents seas: compositon and origin. Polar Res. 24:95-110.

Ronquist, F. \& Huelsenbeck, J. P. 2003. MrBayes version 3.0: Bayesian phylogenetic inference under mixed models. Bioinformatics 19:1572-74.

Round, F. E., Crawford, R. M. \& Mann, D. G. 1990. The diatoms. Biology and morphology of the genera. Cambridge University Press, Cambridge. 747 pp.

Różańska, M., Poulin, M. \& Michel, G. 2008. Protist entrapment in newly formed sea ice in the Coastal Arctic Ocean. J. Marine Syst.:887-901.

Ruggiero, M. V., Sarno, D., Barra, L., Kooistra, W. H. C. F., Montresor, M. \& Zingone, A. 2015. Diversity and temporal pattern of Pseudo-nitzschia species (Bacillariophyceae) through the molecular lens. Harmful Algae 42:15-24.

Sarno, D., Kooistra, W. C. H. F., Balzano, S., Hargraves, P. E. \& Zingone, A. 2007. Diversity in the genus Skeletonema (Bacillariophyceae): III. Phylogenetic position and morphological variability of Skeletonema costatum and Skeletonema grevillei, with the description of Skeletonema ardens sp. nov. J. Phycol. 43:156-70. 
Sarno, D., Kooistra, W. C. H. F., Medlin, L. K., Percopo, I. \& Zingone, A. 2005. Diversity in the genus Skeletonema (Bacillariophyceae). II. An assessment of the taxonomy of $S$. costatum-like species, with the description of four new species. J. Phycol. 41: 151-76.

Scott, F. J. \& Thomas, D. P. 2005. Diatoms. In Scott, F. J. \& Marchant, H. J. [Eds.] Antarctic marine protists. Canberra \& Hobart: Australian Biological Resources Study; Australian Antarctic Division, pp. 13-201.

Sukhanova, I. N., Flint, M. V., Pautova, L. A., Stockwell, D. A., M., G. J. \& Sergeeva, V. M. 2009. Phytoplankton of the western Arctic in the spring and summer of 2002: structure and seasonal changes. Deep Sea Res.II 56:1223-36.

Tammilehto, A., Nielsen, T. G., Krock, B., Møller, E. F. \& Lundholm, N. 2012. Calanus spp.- - vectors for the biotoxin, domoic acid, in the Arctic marine ecosystem? Harmful Algae 20:165-74.

Tammilehto, A., Nielsen, T. G., Krock, B., Møller, E. F. \& Lundholm, N. 2015. Induction of domoic acid production in the toxic diatom Pseudo-nitzschia seriata by calanoid copepods. Aquat. Toxicol. 159:52-61.

Tamura, K., Peterson, D., Peterson, N., Stecher, G., Nei, M. \& Kumar, S. 2011. MEGA5:

Molecular evolutionary genetics analysis using Maximum Likelihood, Evolutionary Distance, and Maximum Parsimony methods. Mol. Biol. Evol. 28:2731-39. 
Teng, S. T., Lim, H. C., Lim, P. T., Dao, V. H., Bates, S. S. \& Leaw, C. P. 2014. Pseudonitzschia kodamae sp. nov. (Bacillariophyceae), a toxigenic species from the Strait of Malacca, Malaysia. Harmful Algae 34:17-28.

Teng, S. T., Lim, P. T., Lim, H. C., Rivera-Vilarelle, M., Quijano-Scheggia, S., Takata, Y., Quilliam, M. A., Wolf, M., Bates, S. S. \& Leaw, C. P. 2015. A non-toxigenic but morphologically and phylogenetically distinct new species of Pseudo-nitzschia, P. sabit sp. nov. (Bacillariophyceae). J. Phycol. 51:706-25.

Trainer, V. L., Bates, S. S., Lundholm, N., Thessen, A. E., Cochlan, W. P., Adams, N. G. \& Trick, C. G. 2012. Pseudo-nitzschia physiological ecology, phylogeny, toxicity, monitoring and impacts on ecosystem health. Harmful Algae 14:271-300.

Tuschling, K., Von Juterzenka, K., Okolodkov, Y. \& Anoshkin, A. 2000. Composition and distribution of the pelagic and sympagic algal assemblages in the Laptev Sea during autumnal freeze-up. J. Plankton Res. 20:843-64.

Vanormelingen, P., Chepurnov, V. A., Mann, D. G., Cousin, S. \& Vyverman, W. 2007. Congruence of morphological, reproductive and ITS rDNA sequence data in some Australasian Eunotia bilunaris (Bacillariophyta). Eur. J. Phycol. 42:61-79.

von Quillfeldt, C. H. 1997. Distribution of diatoms in the Northeast Polynya, Greenland. J. Marine Syst. 10:211-40. 
von Quillfeldt, C. H. 2000. Common diatom species in arctic spring blooms: their distribution and abundance. Bot. Mar. 43:499-516.

Vrieling, E. G., Sun, Q., Tian, M., Kooyman, P. J., Gieskes, W. W. C., van Santen, R. A. \& Sommerdijk, N. A. J. M. 2007. Salinity-dependent diatom biosilicification implies an important role of external ionic strength. Proc. Nat. Acad. Sci. USA 104:10441-46.

Wassmann, P., Ratkova, T. N., Andreassen, I., Vernet, M., Pedersen, G. \& Rey, F. 1999. Spring bloom development in the marginal ice zone and the central Barents Sea. Mar. Ecol.Evol. Persp. 20:321-46.

White, T. J., Bruns, T., Lee, S. \& Taylor, J. 1990. Amplification and direct sequencing of fungal ribosomal RNA genes for phylogenetics. In Innis, M. A., Gelfand, D. H., Sninsky, J. J. \& White, T. J. [Eds.] PCR protocols. Academic Press, New York, pp. 315-22.

Wolf, M., Achtziger, M., Schultz, J., Dandekar, T. \& Muller, T. 2005. Homology modeling revealed more than 20,000 rRNA internal transcribed spacer 2 (ITS2) secondary structures. RNA 11:1616-23.

Zuker, M., Mathews, D. H. \& Turner., D. H. 1999. Algorithms and Thermodynamics for RNA Secondary Structure Prediction: A Practical Guide. In: Barciszewski, J., Clark, B. F. C. [Eds.] RNA Biochemistry and Biotechnology. Springer, Netherlands, pp. 11-43. 
Table 1: Strain designation, isolation site and date, and accession numbers for cultures of Pseudo-nitzschia established for the present study.

\begin{tabular}{|c|c|c|c|c|c|c|c|}
\hline Species & Strain designation & Isolation site & $\begin{array}{c}\text { Station } \\
\text { coordinates }\end{array}$ & $\begin{array}{l}\text { Collection } \\
\text { date }\end{array}$ & $\begin{array}{l}\text { Accession } \\
\text { number } \\
\text { (LSU) }\end{array}$ & $\begin{array}{c}\text { Accession } \\
\text { number (ITS) }\end{array}$ & $\begin{array}{c}\text { Accession } \\
\text { number }(r b c \mathrm{~L})\end{array}$ \\
\hline $\begin{array}{l}P . \\
\text { arctica }\end{array}$ & RCC2002 & Beaufort Sea & $\begin{array}{l}\text { Latitude } \\
{\left[{ }^{\circ} \mathrm{N}\right]-} \\
\text { Longitude } \\
{\left[{ }^{\circ} \mathrm{W}\right]}\end{array}$ & August 2009 & JQ995416 & KT808253 & KT808257 \\
\hline $\begin{array}{l}P . \\
\text { arctica }\end{array}$ & RCC2004 & Beaufort Sea & $69.49-137.94$ & August 2009 & JQ995418 & KT808254 & As KT808257 \\
\hline $\begin{array}{l}P . \\
\text { arctica }\end{array}$ & RCC2005 & Beaufort Sea & $69.49-137.94$ & August 2009 & JQ995419 & KT808255 & KT808258 \\
\hline $\begin{array}{l}P . \\
\text { arctica }\end{array}$ & RCC2517 & Beaufort Sea & $69.49-137.94$ & August 2010 & JQ995461 & KT808256 & KP757864 \\
\hline $\begin{array}{l}P . \\
\text { arctica }\end{array}$ & $\mathrm{P} 2 \mathrm{~F} 2$ & $\begin{array}{l}\text { Disko Bay, } \\
\text { West } \\
\text { Greenland }\end{array}$ & 69.49-137.94 & April 2010 & KU212806 & KT589421 & \\
\hline $\begin{array}{l}P . \\
\text { arctica }\end{array}$ & $\begin{array}{l}\text { CCMP1309=syn } \\
\text { K1142 }\end{array}$ & $\begin{array}{l}\text { Barrow } \\
\text { Strait, Baffin } \\
\text { Bay }\end{array}$ & $69.14-53.23$ & May 1989 & As above & AY556482 & \\
\hline
\end{tabular}


Table 2: Morphometric data of $P$. arctica compared to species of the $P$. pseudodelicatissima complex and $P$. granii and $P$. subcurvata.

\begin{tabular}{|c|c|c|c|c|c|c|c|c|c|c|c|}
\hline \multirow{3}{*}{ Species } & \multirow{3}{*}{ Reference } & \multicolumn{3}{|c|}{ Valves } & \multirow{3}{*}{$\begin{array}{l}\text { Fibulae in } \\
\qquad 10 \mu \mathrm{m}\end{array}$} & \multirow{3}{*}{$\begin{array}{l}\text { Central } \\
\text { nodule }\end{array}$} & \multirow{3}{*}{$\begin{array}{l}\text { Interstriae in } \\
\qquad 10 \mu \mathrm{m}\end{array}$} & \multicolumn{2}{|c|}{ Poroids } & \multicolumn{2}{|c|}{ Intercalary bands } \\
\hline & & & & & & & & \multirow{2}{*}{$\begin{array}{l}\text { Poroids } \\
\text { in } 1 \mu \mathrm{m}\end{array}$} & \multirow{2}{*}{$\begin{array}{l}\text { Sectors } \\
\text { in } \\
\text { poroids }\end{array}$} & \multirow{2}{*}{$\begin{array}{l}\text { Band striae } \\
\text { in } 10 \mu \mathrm{m}\end{array}$} & \multirow{2}{*}{$\begin{array}{c}\text { Valvocopula } \\
\text { striae: poroids } \\
\text { wide x poroids } \\
\text { high }\end{array}$} \\
\hline & & Valve shape & $\begin{array}{l}\text { Width } \\
(\mu \mathrm{m})\end{array}$ & $\begin{array}{l}\text { Length } \\
(\mu \mathrm{m})\end{array}$ & & & & & & & \\
\hline \multirow[t]{3}{*}{ P. arctica } & This study & Lanceolate & $1.6-2.5$ & $26-67$ & $17-24$ & + & $33-39$ & $4-6$ & $0-5$ var. & $41-48$ & $2 \times 1-3$ \\
\hline & & & $1.9 \pm 0.2$ & $53.7 \pm 13.4$ & $20.4 \pm 1.7$ & & $35.9 \pm 1.5$ & $5.5 \pm 0.5$ & & $44.3 \pm 2.0$ & \\
\hline & & & $(\mathrm{n}=61)$ & $(\mathrm{n}=20)$ & $(n=100)$ & & $(n=106)$ & $(\mathrm{n}=106)$ & & $(n=63)$ & \\
\hline \multirow[t]{2}{*}{ P. abrensis } & Orive et al. & Linear to & $1.7-2.5$ & $66.5-74.1$ & $16-22$ & + & $30-37$ & $4-6$ & $1-4$ & $36-38$ & $2 \times 2-4$ \\
\hline & (2013) & lanceolate & $2.0 \pm 0.2$ & & $18.6 \pm 1.3$ & & $32.8 \pm 2.0$ & $5.2 \pm 0.4$ & $2.3 \pm 0.5$ & $36.8 \pm 0.8$ & \\
\hline \multirow[t]{2}{*}{ P. batesiana } & Lim et al. & Lanceolate & $1.8-2.2$ & $84-86$ & $15-19$ & + & $29-32$ & $5-6$ & $2-3$ & $40-43$ & $2 \times 3-4$ \\
\hline & (2013) & & $2.0 \pm 0.2$ & $84.8 \pm 1.0$ & $17.0 \pm 2.0$ & & $30.6 \pm 1.6$ & $5.5 \pm 0.5$ & $2.6 \pm 0.6$ & $41.3 \pm 1.5$ & \\
\hline \multirow[t]{3}{*}{ P. caciantha } & Lundholm & Lanceolate & $2.7-3.5$ & $53-75$ & $15-19$ & + & $28-31$ & $3.5-5$ & $4-5$ & $33-38$ & $2 \times 3-5$ \\
\hline & Amato et al. & Lanceolate & $2.2-3.0$ & nd & $18-23$ & + & $33-37$ & $3-5$ & $2-6$ & nd & nd \\
\hline & (2007) & & $2.6 \pm 0.2$ & & $20.7 \pm 1.5$ & & $34.9 \pm 1.5$ & $4.6 \pm 0.1$ & $3.1 \pm 1.0$ & & \\
\hline
\end{tabular}




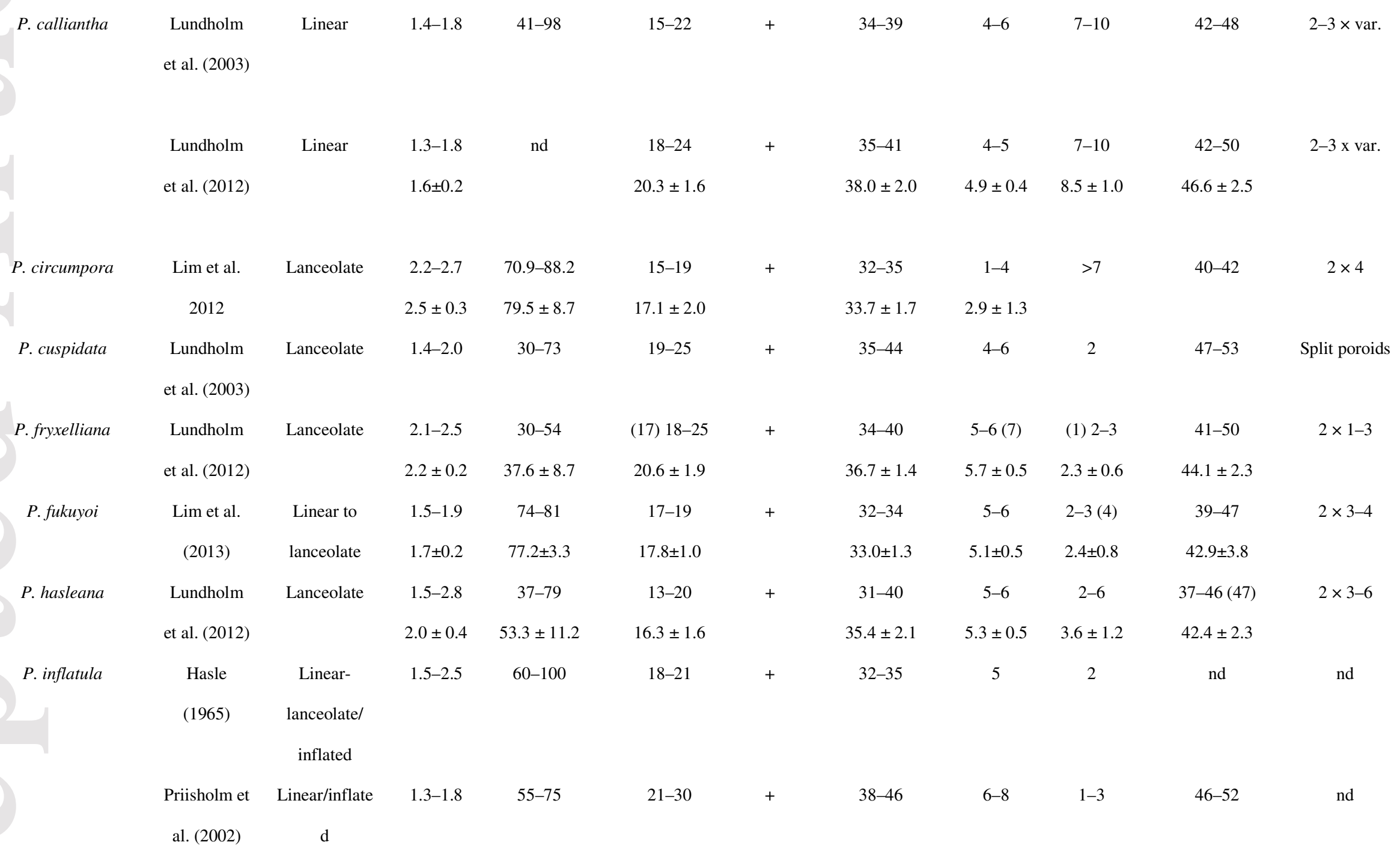




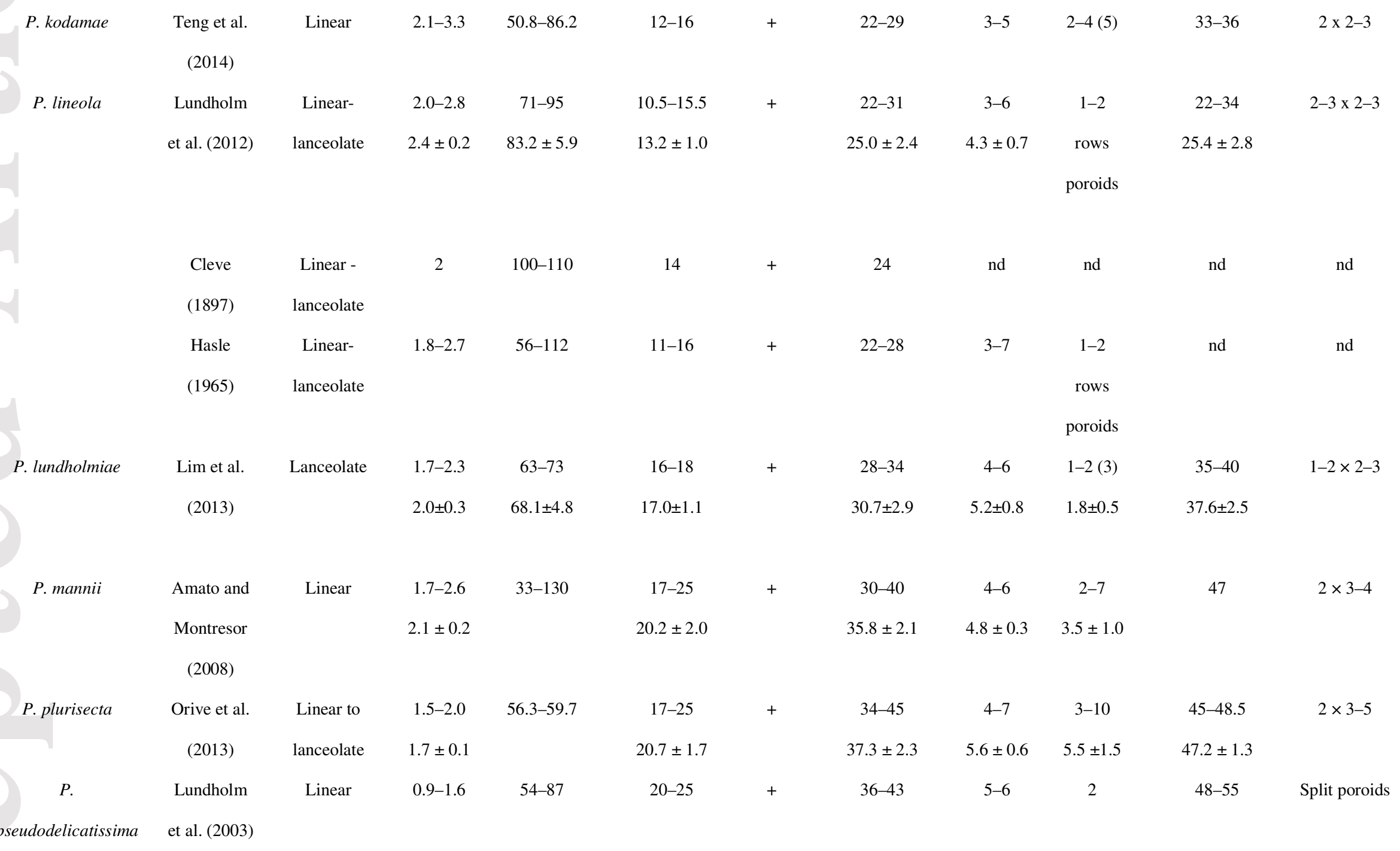




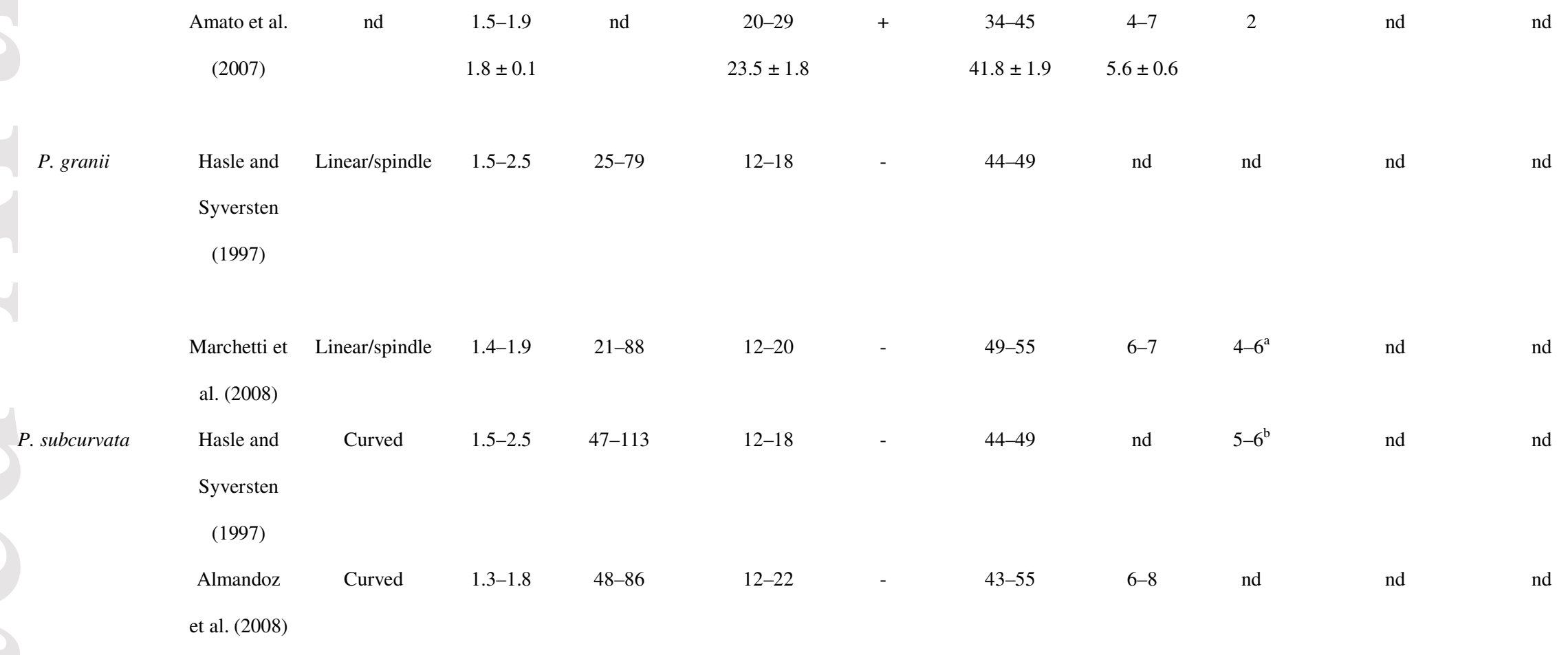

Data are given as minimum and maximum range (above), and mean value \pm standard deviation (below). nd, no data; var, variable.

${ }^{a}$ Not in the text but inferred from plate 13, fig. 7a, in Hasle 1964, and fig. 2, in Marchetti et al. 2008.

${ }^{\mathrm{b}}$ Not in the text but inferred from plate 13, figs. 2a and 4, in Hasle 1964. 
Table 3: Net average nucleotide distance among $P$. arctica, $P$. granii, $P$. subcurvata and $P$. fryxelliana.

\begin{tabular}{llll}
\hline ITS/ITS2 & P. arctica & P. granii & subcurvata \\
LSU/rbcL & & & \\
\hline P. granii & $0.019 / 0.032$ & & \\
& n.a./n.a. & & \\
& & & \\
& $0.019 / 0.024$ & $0.007 / 0.0$ & \\
P. subcurvata & $0.012 / 0.034$ & 08 & \\
& & n.a./n.a. & \\
& & $0.143 / 0.2$ & $0.141 / 0.205$ \\
$P$. fryxelliana & $0.133 / 0.206$ & 05 & $0.030 / 0.060$ \\
& $0.024 / 0.041$ & n.a./n.a. & \\
\hline
\end{tabular}

n.a., information not available.

\section{LEGENDS}

Figure 1: LM (A) and TEM micrographs (B-I) of Pseudo-nitzschia arctica sp. nov. (A) Strain RCC2004. Part of a colony in girdle view. (B) Strain P2F2. Whole cell. (C and D) Strain RCC2004. Valve ends. (E) Strain P2F2. Central part of the valve with central nodule. (F) Strain RCC2005. Part of valve with mantle and cingular bands. (G) Strain RCC2004. Central part of the valve showing stria structure. Note the well-formed poroids. (H) Strain RCC2005. Part of valve with poroids with less silicified areas. (I) Strain P2F2. Particular of poroid structure. Note missing poroids and sectors. (J) Strain RCC2005. The three cingular bands. Arrows indicate borders of bands: $\mathrm{V}=$ valvocopula, $\mathrm{II}=$ second cingular band, $\mathrm{III}=$ third cingular band. (K) Strain P2F2. Valvocopula and second cingular band. (L) Strain P2F2. Second and third cingular bands with small pores. Scale bars: $(A)=10 \mu \mathrm{m},(B)=5 \mu \mathrm{m},(\mathrm{C}$, 
$\mathrm{E}, \mathrm{F}, \mathrm{G}, \mathrm{H})=1 \mu \mathrm{m},(\mathrm{D}, \mathrm{J}, \mathrm{K}, \mathrm{L})=0.5 \mu \mathrm{m},(\mathrm{I})=0.2 \mu \mathrm{m}$.

Figure 2: Phylogenetic tree from maximum likelihood (ML) analysis based on Pseudonitzschia ITS1-5.8S-ITS2 region of the ribosomal RNA. The tree is unrooted. Black circle indicates boostrap support and bayesian posterior probabilities on $>70 \%$ and $95 \%$, respectively; grey circle indicates boostrap support below $70 \%$ and bayesian posterior probabilities on $95 \%$; grey diamond indicates boostrap support on $70 \%$ and bayesian posterior probabilities below 95\%. Asterisks * indicate the species belonging to the $P$. pseudodelicatissima complex.

Figure 3: Phylogenetic tree from ML analysis based on Pseudo-nitzschia $r b c \mathrm{~L}$. The tree was rooted with Cylindrotheca sp. M59080. Black circle indicates boostrap support and bayesian posterior probabilities on $>70 \%$ and $95 \%$, respectively; grey circle indicates boostrap support below $70 \%$ and bayesian posterior probabilities on $95 \%$; grey diamond indicates boostrap support on $70 \%$ and bayesian posterior probabilities below $95 \%$. Asterisks * indicate the species belonging to the $P$. pseudodelicatissima complex.

Figure 4: ITS2 secondary structure of the holotype strain RC2005 for Pseudo-nitzschia arctica. Helices are named according to Amato et al. (2007) (roman numbers). The boxes indicate the structural variations found in $P$. arctica with respect to $P$. granii and $P$. subcurvata. Please note that the ITS2 from $P$. granii and $P$. subcurvata differ only by one nucleotide located on the helix IV, whereas it is identical for the rest of the ITS-2 sequence. Nucleotides which differ between $P$. arctica and the other two species are marked with black background, whereas insertions are noted with grey background. 


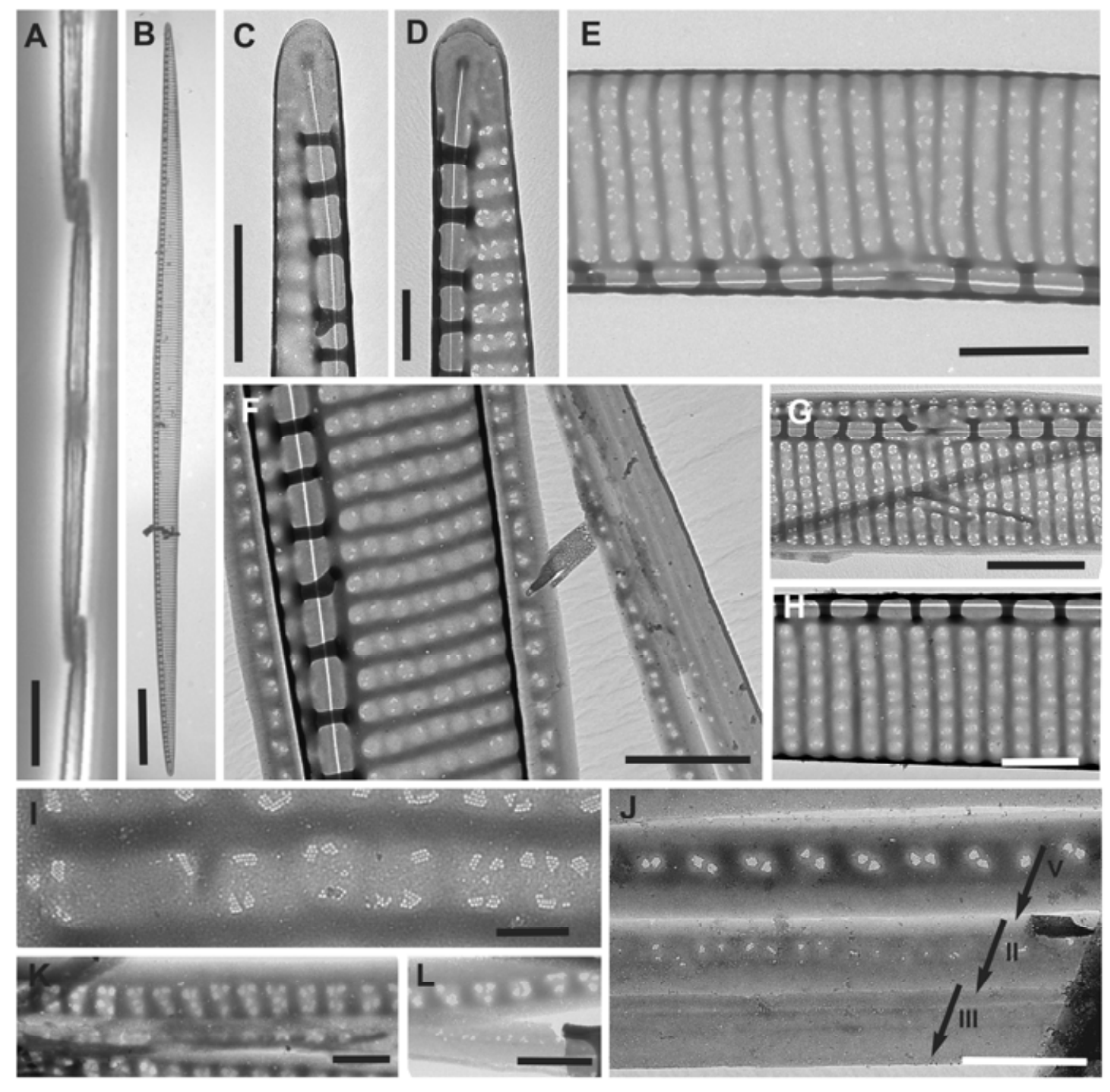




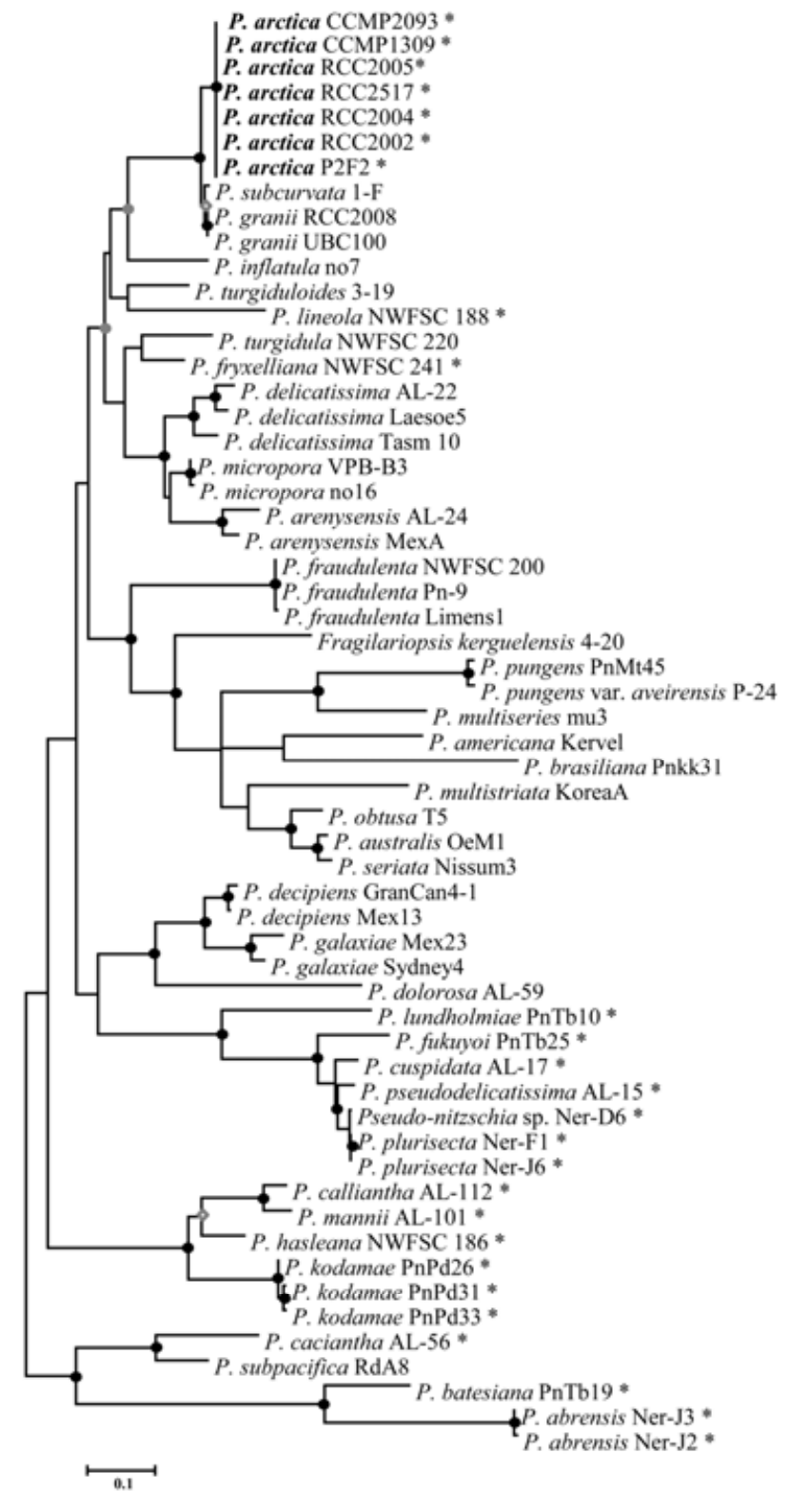

- $\mathrm{ML}>70 \%, \mathrm{BI}>0.95$

- $\mathrm{ML}<70 \%, \mathrm{BI}>0.95$

$\diamond \mathrm{ML}>70 \%, \mathrm{BI}<0.95$

$\mathrm{ML}<70 \%, \mathrm{BI}<0.95$ 


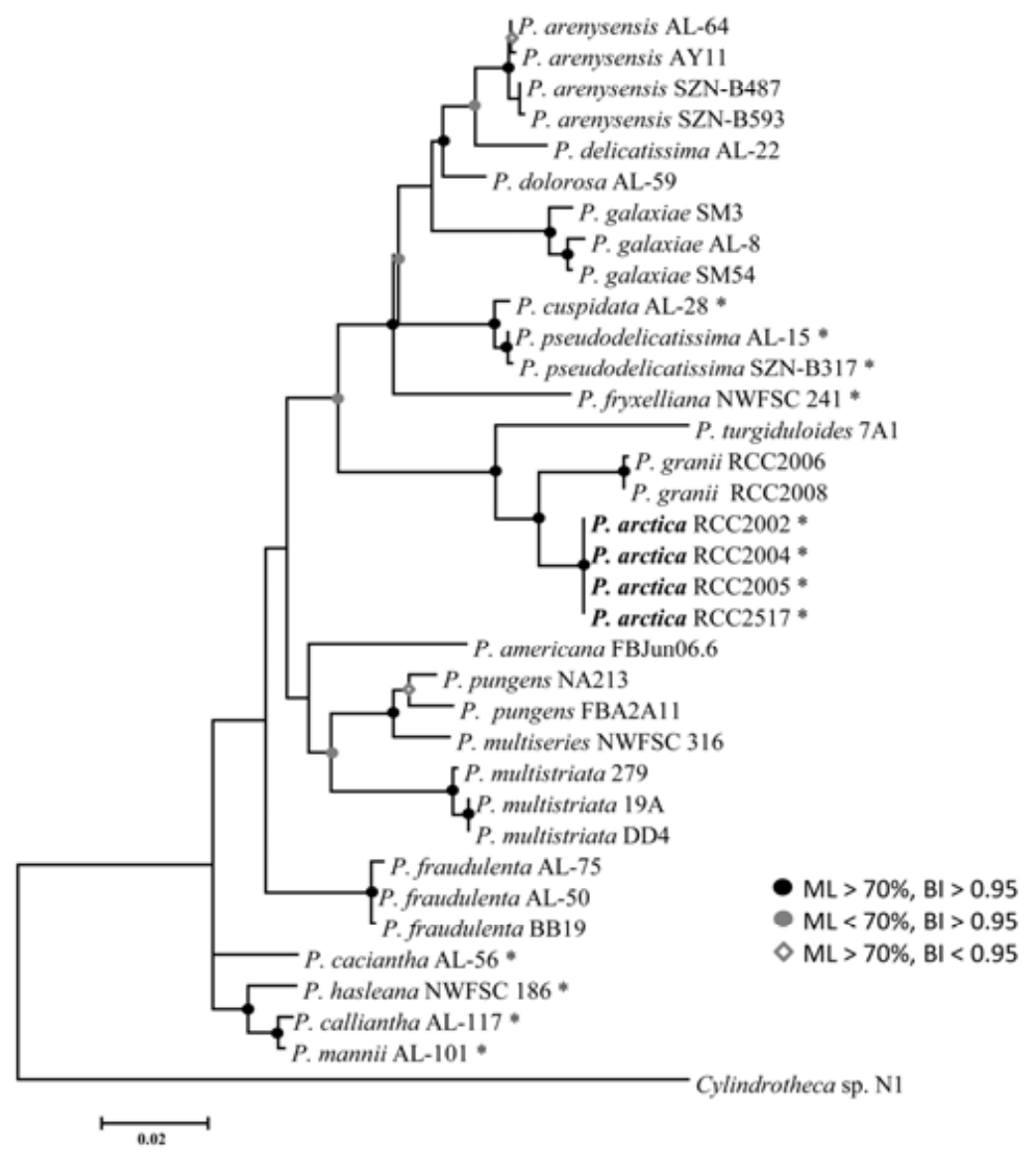




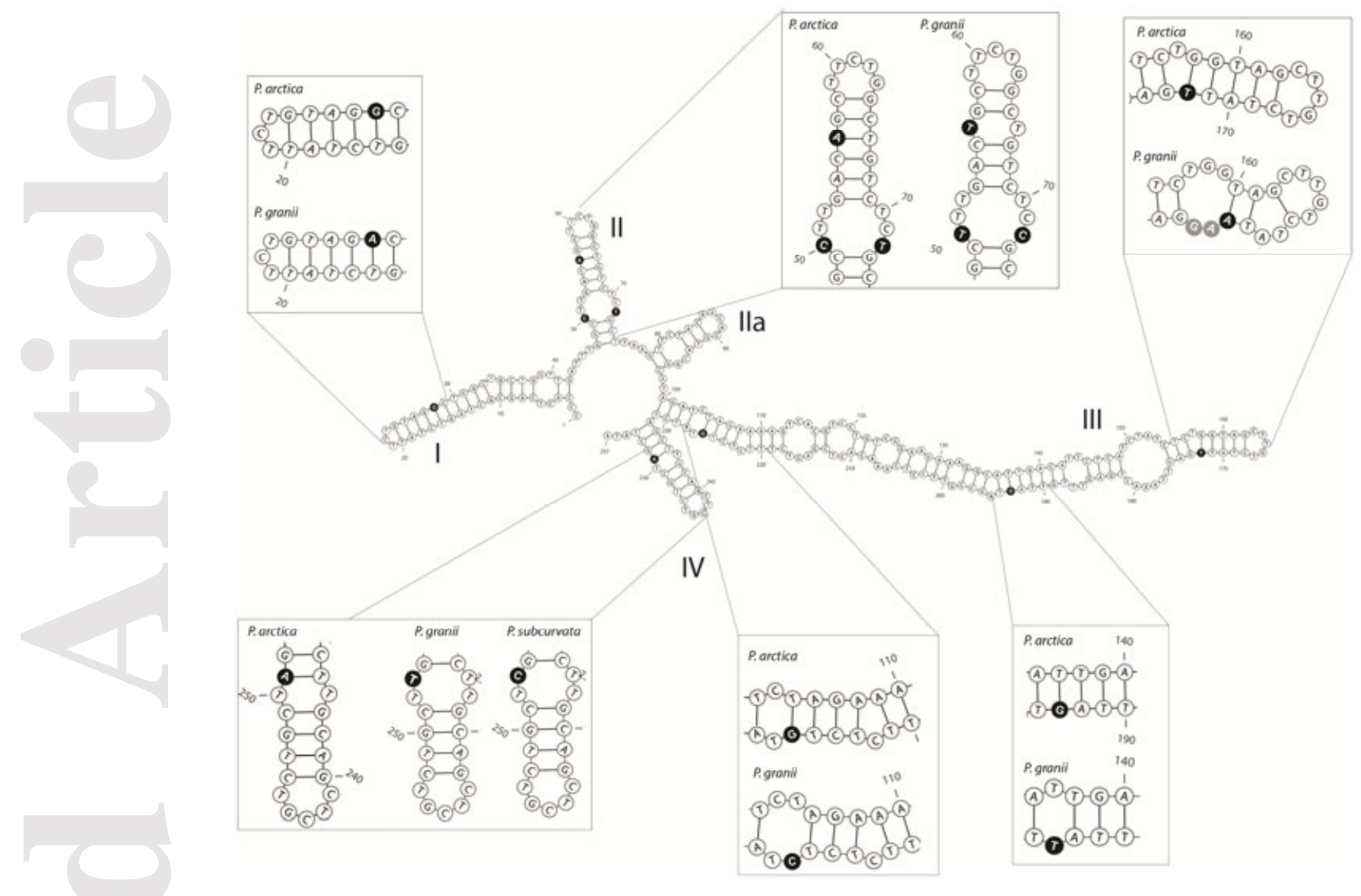

